\title{
Simulation of polar stratospheric clouds in the chemistry-climate-model EMAC via the submodel PSC
}

\author{
O. Kirner ${ }^{1}$, R. Ruhnke ${ }^{2}$, J. Buchholz-Dietsch ${ }^{4}$, P. Jöckel ${ }^{3}$, C. Brühl ${ }^{4}$, and B. Steil ${ }^{4}$ \\ ${ }^{1}$ Karlsruhe Institute of Technology, Steinbuch Centre for Computing (SCC), Karlsruhe, Germany \\ ${ }^{2}$ Karlsruhe Institute of Technology, Institute for Meteorology and Climate Research (IMK), Karlsruhe, Germany \\ ${ }^{3}$ Deutsches Zentrum für Luft- u. Raumfahrt (DLR), Institut für Physik der Atmosphäre, Oberpfaffenhofen, Weßling, Germany \\ ${ }^{4}$ Max Planck Institute for Chemistry (MPIC), Mainz, Germany
}

Received: 17 September 2010 - Published in Geosci. Model Dev. Discuss.: 4 November 2010

Revised: 16 February 2011 - Accepted: 25 February 2011 - Published: 11 March 2011

\begin{abstract}
The submodel PSC of the ECHAM5/MESSy Atmospheric Chemistry model (EMAC) has been developed to simulate the main types of polar stratospheric clouds (PSC). The parameterisation of the supercooled ternary solutions (STS, type 1b PSC) in the submodel is based on Carslaw et al. (1995b), the thermodynamic approach to simulate ice particles (type 2 PSC) on Marti and Mauersberger (1993). For the formation of nitric acid trihydrate (NAT) particles (type 1a PSC) two different parameterisations exist. The first is based on an instantaneous thermodynamic approach from Hanson and Mauersberger (1988), the second is new implemented and considers the growth of the NAT particles with the aid of a surface growth factor based on Carslaw et al. (2002). It is possible to choose one of this NAT parameterisation in the submodel. This publication explains the background of the submodel PSC and the use of the submodel with the goal of simulating realistic PSC in EMAC.
\end{abstract}

\section{Introduction}

Polar stratospheric clouds are necessary for ozone depletion in polar spring. The activation of inorganic chlorine and bromine substances takes place on their surfaces during the polar winter leading to ozone depletion in polar spring and the denitrification of nitrogen substances and the dehydration of water vapour $\left(\mathrm{H}_{2} \mathrm{O}\right)$ is caused through the sedimentation of NAT and ice particles. The denitrification prevents the deactivation of the active halogen substances such that the ozone depletion lasts longer.
PSC are classified into three subtypes. The type 1a PSC defined as solid NAT particles, the type 1b PSC as liquid STS droplets and solid ice particles form the type 2 PSC.

The exact microphysical and thermodynamical details of PSC development are still a matter of discussion, but a large body of scientific evidence exists that support a number of theories related to their formation, which will be summarised briefly (Lowe and MacKenzie, 2008).

\subsection{The formation of STS (type 1b PSC)}

The formation of STS droplets $\left(\mathrm{HNO}_{3} \cdot \mathrm{H}_{2} \mathrm{SO}_{4} \cdot \mathrm{H}_{2} \mathrm{O}\right)$ is described in Beyer et al. (1994), Carslaw et al. $(1994,1997)$ and Luo et al. (1995). STS form during cooling below a specific temperature threshold through uptake of nitric acid $\left(\mathrm{HNO}_{3}\right)$ by sulphuric acid aerosols $\left(\mathrm{H}_{2} \mathrm{SO}_{4} \cdot \mathrm{H}_{2} \mathrm{O}\right)$, existing in the socalled "Junge Layer" (Junge et al., 1961).

The ternary droplet composition depends on the temperature. In different laboratory measurements it has been shown that during cooling of STS the fraction of $\mathrm{HNO}_{3}$ increases in the droplets, whereas the fraction of $\mathrm{H}_{2} \mathrm{SO}_{4}$ decreases (Tabazadeh et al., 1994; Carslaw et al., 1995a; Luo et al., 1995; Beyer et al., 1994). As shown in Carslaw et al. (1994, 1997) the STS droplets are stable until the temperature drops to the ice frost point. Below the ice frost point freeze the STS droplets. With the uptake of $\mathrm{HNO}_{3}$ into the droplets the volume of the STS particles strongly increases.

Besides the solubility of $\mathrm{HNO}_{3}$, also the solubilities of hydrochloric acid $(\mathrm{HCl})$, hypochlorous acid $(\mathrm{HOCl})$, hydrobromic acid $(\mathrm{HBr})$ and hypobromous acid $(\mathrm{HOBr})$ change during cooling (Carslaw et al., 1997), which is important for the heterogeneous chemistry reactions (see Sect. 1.4).

Correspondence to: O. Kirner

(ole.kirner@kit.edu)

Published by Copernicus Publications on behalf of the European Geosciences Union. 


\subsection{The formation of NAT (type 1a PSC)}

It exist two formation mechanism for NAT particles $\left(\mathrm{HNO}_{3} \cdot\left(\mathrm{H}_{2} \mathrm{O}\right)_{3}\right)$ : (1) the heterogeneous formation of NAT on ice particles (Biermann et al., 1998; Carslaw et al., 1998; Middlebrook et al., 1996; Waibel et al., 1999; Wirth et al., 1999) and (2) the homogeneous nucleation of NAT out of supercooled ternary solutions (Carslaw et al., 2002; Daerden et al., 2007; Tabazadeh et al., 2002).

As found by Hanson and Mauersberger (1988) NAT can exist under stratospheric conditions below the NAT condensation temperature $\left(T_{\mathrm{NAT}}\right)$. $T_{\mathrm{NAT}}$ depends on the pressure and on the partial pressures of $\mathrm{HNO}_{3}$ and $\mathrm{H}_{2} \mathrm{O}$. A typical temperature for $T_{\mathrm{NAT}}$ is approx. $193 \mathrm{~K}$. However observations (Schlager and Arnold, 1990; Dye et al., 1992) indicate that NAT particles do not exist before a supercooling of 2-3 K below $T_{\mathrm{NAT}}$.

Earlier laboratory studies (Middlebrook et al., 1996; Biermann et al., 1998) and lidar observations on aircraft (Carslaw et al., 1998; Wirth et al., 1999) verify the first formation mechanism for NAT, the heterogeneous formation on ice particles. In this case $\mathrm{HNO}_{3}$ is adsorbed on ice particles, for instance if ice particles sediment through air with high $\mathrm{HNO}_{3}$ mixing ratios (Wofsy et al., 1990).

The second formation mechanism for NAT is the homogeneous nucleation of nitric acid dihydrate (NAD, $\left.\mathrm{HNO}_{3} \cdot\left(\mathrm{H}_{2} \mathrm{O}\right)_{2}\right)$ out of STS and the subsequent conversion of the metastable NAD to NAT (Carslaw et al., 2002; Daerden et al., 2007). The NAD condensation temperature $\left(T_{\mathrm{NAD}}\right)$ is approx. $2-3 \mathrm{~K}$ below $T_{\mathrm{NAT}}$ thereby explaining the observations of Schlager and Arnold (1990) and Dye et al. (1992). This formation mechanism is verified through labor studies from Tabazadeh et al. (2002).

\subsection{The formation of ice (type 2 PSC)}

Ice particles are formed in the stratosphere at very low temperatures, typically below the ice frost point $\left(T_{\text {ice }}\right)$ at approx. $188 \mathrm{~K}$.

There are different processes forming ice. It has been debated which of them occur in the polar stratosphere: (1) homogeneous nucleation of ice out of supercooled sulphuric acid (SSA, $\mathrm{H}_{2} \mathrm{SO}_{4} \cdot \mathrm{H}_{2} \mathrm{O}$, Bertram et al., 1996) or out of supercooled ternary solutions (STS, Carslaw et al., 1998; Koop et al., 2000; Tabazadeh et al., 1997); (2) heterogeneous nucleation of ice out of liquid aerosol (SSA, STS) containing insoluble nuclei such as mineral oxides or soot (DeMott et al., 1997; Jensen and Toon, 1997); and (3) heterogeneous nucleation of ice on sulphuric acid tetrahydrate (SAT, $\mathrm{H}_{2} \mathrm{SO}_{4} \cdot\left(\mathrm{H}_{2} \mathrm{O}\right)_{4}$, Fortin et al., 2003).

The first formation mechanism, the homogeneous nucleation of ice out of SSA or SST, is confirmed by different laboratory studies. This formation, however, requires supercooling. Tabazadeh et al. (1997) measured a supercooling of 2 to $3 \mathrm{~K}$, Carslaw et al. (1998) of approx. $4 \mathrm{~K}$ and Daer- den et al. (2007, deduced from Koop et al., 2000) of 3 to $4 \mathrm{~K}$ compared to the ice frost point.

In contrast, theoretical work suggests that the second formation mechanism, the heterogeneous nucleation of ice out of SSA or STS with mineral oxide or soot as nuclei, may occur at temperatures warmer than those required for homogeneous nucleation (DeMott et al., 1997; Jensen and Toon, 1997). This mechanism is perhaps possible for the upper troposphere, where these nuclei exist, but improbable for the stratosphere (Fortin et al., 2003).

The third formation mechanism of ice particles, the deposition from water vapour on firm SAT particles introduced in Fortin et al. (2003) is most likely very relevant in the polar polar stratosphere. It takes place at temperatures close to the ice frost point. In the laboratory studies of Fortin et al. (2003) only a supercooling of $0.1 \mathrm{~K}$ to $1.3 \mathrm{~K}$ was necessary for the formation.

\subsection{Polar ozone depletion}

PSCs are fundamental for the understanding of ozone depletion in polar spring. On the surfaces of the liquid and solid PSC particles the following heterogeneous reactions occur (Abbatt and Molina, 1992; Crutzen et al., 1992; Hanson and Ravishankara, 1991, 1993; Solomon et al., 1986; Tolbert et al., 1987):

$$
\begin{aligned}
& \mathrm{N}_{2} \mathrm{O}_{5}(\mathrm{~g})+\mathrm{H}_{2} \mathrm{O}(\mathrm{l}, \mathrm{s}) \stackrel{\text { het }}{\longrightarrow} 2 \mathrm{HNO}_{3}(\mathrm{l}, \mathrm{s}) \\
& \mathrm{N}_{2} \mathrm{O}_{5}(\mathrm{~g})+\mathrm{HCl}(\mathrm{l}, \mathrm{s}) \stackrel{\text { het }}{\longrightarrow} \mathrm{ClNO}_{2}(\mathrm{~g})+\mathrm{HNO}_{3}(\mathrm{l}, \mathrm{s}) \\
& \mathrm{ClONO}_{2}(\mathrm{~g})+\mathrm{H}_{2} \mathrm{O}(\mathrm{l}, \mathrm{s}) \stackrel{\text { het }}{\longrightarrow} \mathrm{HOCl}(\mathrm{g})+\mathrm{HNO}_{3}(\mathrm{l}, \mathrm{s}) \\
& \mathrm{ClONO}_{2}(\mathrm{~g})+\mathrm{HCl}(\mathrm{l}, \mathrm{s}) \stackrel{\text { het }}{\longrightarrow} \mathrm{Cl}_{2}(\mathrm{~g})+\mathrm{HNO}_{3}(\mathrm{l}, \mathrm{s}) \\
& \mathrm{ClONO}_{2}(\mathrm{~g})+\mathrm{HBr}(1, \mathrm{~s}) \stackrel{\text { het }}{\longrightarrow} \mathrm{BrCl}(\mathrm{g})+\mathrm{HNO}_{3}(1, \mathrm{~s}) \\
& \mathrm{BrONO}_{2}(\mathrm{~g})+\mathrm{H}_{2} \mathrm{O}(\mathrm{l}, \mathrm{s}) \stackrel{\text { het }}{\longrightarrow} \mathrm{HOBr}(\mathrm{g})+\mathrm{HNO}_{3}(\mathrm{l}, \mathrm{s}) \\
& \mathrm{BrONO}_{2}(\mathrm{~g})+\mathrm{HCl}(1, \mathrm{~s}) \stackrel{\text { het }}{\longrightarrow} \mathrm{BrCl}(\mathrm{g})+\mathrm{HNO}_{3}(1, \mathrm{~s}) \\
& \mathrm{HOCl}(\mathrm{g})+\mathrm{HCl}(\mathrm{l}, \mathrm{s}) \stackrel{\text { het }}{\longrightarrow} \mathrm{Cl}_{2}(\mathrm{~g})+\mathrm{H}_{2} \mathrm{O}(\mathrm{l}, \mathrm{s}) \\
& \mathrm{HOCl}(\mathrm{g})+\mathrm{HBr}(\mathrm{l}, \mathrm{s}) \stackrel{\text { het }}{\longrightarrow} \mathrm{BrCl}(\mathrm{g})+\mathrm{H}_{2} \mathrm{O}(\mathrm{l}, \mathrm{s}) \\
& \mathrm{HOBr}(\mathrm{g})+\mathrm{HCl}(1, \mathrm{~s}) \stackrel{\text { het }}{\longrightarrow} \mathrm{BrCl}(\mathrm{g})+\mathrm{H}_{2} \mathrm{O}(\mathrm{l}, \mathrm{s}) \\
& \mathrm{HOBr}(\mathrm{g})+\mathrm{HBr}(\mathrm{l}, \mathrm{s}) \stackrel{\text { het }}{\longrightarrow} \mathrm{Br}_{2}(\mathrm{~g})+\mathrm{H}_{2} \mathrm{O}(\mathrm{l}, \mathrm{s})
\end{aligned}
$$

The products of these reactions: molecular chlorine $\left(\mathrm{Cl}_{2}\right)$, molecular bromine $\left(\mathrm{Br}_{2}\right), \mathrm{HOCl}, \mathrm{HOBr}$, nitryl chloride $(\mathrm{ClNO} 2)$ and bromine chloride $(\mathrm{BrCl})$ are in gas phase $(\mathrm{g})$; $\mathrm{HNO}_{3}$ and $\mathrm{H}_{2} \mathrm{O}$ are in liquid (l) or solid phase (s).

During polar spring the gas phase products photolyse and ozone depleting radicals are formed (Reactions R12-R17):

$$
\begin{aligned}
& \mathrm{Cl}_{2}+h v \rightarrow 2 \mathrm{Cl} \\
& \mathrm{Br}_{2}+h v \rightarrow 2 \mathrm{Br}
\end{aligned}
$$




$$
\begin{aligned}
\mathrm{HOCl}+h v & \rightarrow \mathrm{OH}+\mathrm{Cl} \\
\mathrm{HOBr}+h v & \rightarrow \mathrm{OH}+\mathrm{Br} \\
\mathrm{ClNO}_{2}+h v & \rightarrow \mathrm{Cl}+\mathrm{NO}_{2} \\
\mathrm{BrCl}+h v & \rightarrow \mathrm{Br}+\mathrm{Cl}
\end{aligned}
$$

The radicals deplete ozone in catalytic cycles. One example of such a catalytic cycle is the ozone depletion with $\mathrm{Cl}$ after Molina and Molina (1987):

$$
\begin{aligned}
2\left[\mathrm{Cl}+\mathrm{O}_{3}\right. & \left.\rightarrow \mathrm{ClO}+\mathrm{O}_{2}\right] \\
\mathrm{ClO}+\mathrm{ClO}+\mathrm{M} & \rightarrow \mathrm{Cl}_{2} \mathrm{O}_{2}+\mathrm{M} \\
\mathrm{Cl}_{2} \mathrm{O}_{2}+h v & \rightarrow 2 \mathrm{Cl}+\mathrm{O}_{2} \\
\mathrm{Net}: 2 \mathrm{O}_{3}+h v & \rightarrow 3 \mathrm{O}_{2}
\end{aligned}
$$

The self-reaction of the chlorine monoxide radicals $(\mathrm{ClO})$ form a chlorine monoxide dimer $\left(\mathrm{Cl}_{2} \mathrm{O}_{2}\right)$ in this cycle.

Through the heterogeneous reactions on the surface of PSC particles and the subsequent photolysis in polar spring it is possible to explain the polar ozone depletion quantitatively (Graedel and Crutzen, 1993).

\section{The EMAC model}

The Chemistry Climate Model (CCM) EMAC (ECHAM5/MESSy Atmospheric Chemistry model; Jöckel et al., 2006) has been developed at the Max-Planck-Institute for Chemistry in Mainz. EMAC is a combination of the general circulation model ECHAM5 (Roeckner et al., 2006) and different submodels such as the chemistry submodel MECCA1 (Sander et al., 2005) combined through the Modular Earth Submodel System (MESSy, Jöckel et al. (2005)).

In the vertical EMAC simulates (in a middle atmosphere setup) the atmosphere from the ground to $0.01 \mathrm{hPa}$ (approx. $80 \mathrm{~km}$ ), i.e., including the troposphere, stratosphere and mesosphere. Data are exchanged between the base model (ECHAM5) and the submodels within one comprehensive model system. With the generalized interface structure MESSy the standardized control of the submodels and their interconnections is possible.

Besides the submodel PSC for the simulation of polar stratospheric clouds and MECCA1 for the gas-phase chemistry we have used for our performed EMAC simulation (see Sect. 5) the following submodels: OFFLEM for offline emissions of trace gases and aerosols (Kerkweg et al., 2006b), TNUDGE for tracer nudging (Kerkweg et al., 2006b), DRYDEP for dry deposition of trace gases and aerosols (Kerkweg et al., 2006a), SEDI for the sedimentation of aerosol particles (Kerkweg et al., 2006a), JVAL for the calculation of photolysis rates (Landgraf and Crutzen, 1998), SCAV for the scavenging and liquid phase chemistry in cloud and precipitation (Tost et al., 2006a), CONVECT for the parameterization of convection (Tost et al., 2006b), LNOX for the source of $\mathrm{NO}_{\mathrm{x}}$ produced by lightning (Tost et al., 2007b), PTRAC for additional prognostic tracers (Jöckel et al., 2008), CVTRANS for convective tracer transport (Tost et al., 2010), TROPOP for diagnosing the tropopause and boundary layer height, $\mathrm{H} 2 \mathrm{O}$ for stratospheric water vapour, RAD4ALL for the radiation calculation, HETCHEM for calculating reaction coefficients of heterogeneous reactions on aerosols (see Jöckel et al., 2006, and references therein), and CLOUD for calculating the cloud cover as well as cloud microphysics including precipitation (Tost et al., 2007a).

\section{The submodel PSC}

The submodel PSC is based on the "Mainz Photochemical Box Model" (Crutzen et al., 1992; Grooß, 1996; Meilinger, 2000; Müller, 1994) and was improved amongst others by Buchholz (2005) and Kirner (2008). It includes the simulation of the different PSC types. In the submodel parameterisations for the formation of STS droplets, the formation of NAT particles and the formation of ice particles exist. Moreover, it describes the sedimentation of these particles and the calculation of the heterogeneous chemistry reaction rate coefficients, which take place on the surface of the PSC particles.

For the simulation of NAT particels there was until EMAC version 1.8 only the thermodynamic parameterisation (described in Sect. 3.2.1) implemented in the submodel. A new parameterisation for NAT particles based on the efficient growth and sedimentation algorithm of van den Broek et al. (2004) and Carslaw et al. (2002) has been implemented (described in Sect. 3.2.2) and is available since EMAC version 1.9 (released 2010).

\subsection{The parameterisation of STS droplets and stratospheric liquid aerosols}

The simulation of STS droplets (type 1b PSC) is implemented in the computation of stratospheric liquid aerosol and based on Carslaw et al. (1995b). With the aid of several parameterisations the fractions of $\mathrm{H}_{2} \mathrm{SO}_{4}, \mathrm{HNO}_{3}, \mathrm{H}_{2} \mathrm{O}$, as well as $\mathrm{HCl}, \mathrm{HOCl}, \mathrm{HBr}$ and $\mathrm{HOBr}$ in SSA and STS are calculated. These parameterisations from Carslaw et al. (1995b) are valid for the temperature range $185 \mathrm{~K} \leq T \leq 240 \mathrm{~K}$.

- The first step is the computation of the molar fractions (in mol kg ${ }^{-1}$ ) of $\mathrm{H}_{2} \mathrm{SO}_{4}\left(b \mathrm{H}_{2} \mathrm{SO}_{4}\right.$ (binary)) and $\mathrm{HNO}_{3}$ $\left(b \mathrm{HNO}_{3}\right.$ (binary)) in the supercooled binary solutions $\left(\mathrm{H}_{2} \mathrm{SO}_{4} \cdot \mathrm{H}_{2} \mathrm{O}(\mathrm{SSA})\right.$ and $\left.\mathrm{HNO}_{3} \cdot \mathrm{H}_{2} \mathrm{O}\right)$. Each fraction depends on pressure, temperature and on the mixing ratio of $\mathrm{H}_{2} \mathrm{O}$. At temperatures above $215 \mathrm{~K}$ the liquid fraction of $\mathrm{HNO}_{3}$ is set to zero.

- In the second step the liquid molar fractions of $\mathrm{H}_{2} \mathrm{SO}_{4}$ $\left(b \mathrm{H}_{2} \mathrm{SO}_{4}\right.$ (ternary)) and $\mathrm{HNO}_{3}\left(b \mathrm{HNO}_{3}\right.$ (ternary) $)$ in the droplets are calculated. At temperatures above $215 \mathrm{~K}$ the $b \mathrm{HNO}_{3}$ (ternary) is set to zero. After these calculations the mass fractions (in $\mathrm{kg} \mathrm{kg}^{-1}$ ) of $\mathrm{H}_{2} \mathrm{SO}_{4}$ 
Table 1. Used constants in submodel PSC.

\begin{tabular}{lll}
\hline Constant & Name & Unit \\
\hline$M_{\text {air }}$ & molar mass of air & $0.02897 \mathrm{~kg} \mathrm{~mol}^{-1}$ \\
$M_{\mathrm{H}_{2} \mathrm{O}}$ & molar mass of $\mathrm{H}_{2} \mathrm{O}$ & $0.01802 \mathrm{~kg} \mathrm{~mol}^{-1}$ \\
$M_{\mathrm{H}_{2} \mathrm{SO}_{4}}$ & molar mass of $\mathrm{H}_{2} \mathrm{SO}_{4}$ & $0.09809 \mathrm{~kg} \mathrm{~mol}^{-1}$ \\
$M_{\mathrm{NAT}}$ & molar mass of NAT & $0.117 \mathrm{~kg} \mathrm{~mol}^{-1}$ \\
$\rho_{\text {ice }}$ & the density of ice particles & $990.0 \mathrm{~kg} \mathrm{~m}^{-3}$ \\
$\rho_{\mathrm{NAT}}$ & the crystal mass density of NAT & $1626.0 \mathrm{~kg} \mathrm{~m}^{-3}$ \\
$R_{\text {gas }}$ & universal gas constant & $8.314 \mathrm{~J}\left(\mathrm{~K} \mathrm{~mol}^{-1}\right.$ \\
$N_{\mathrm{A}}$ & Avogadro constant & $6.022 \times 10^{23} \mathrm{~mol}^{-1}$ \\
$g$ & acceleration of gravity & $9.80665 \mathrm{~m} \mathrm{~s}^{-2}$ \\
\hline
\end{tabular}

$\left(w \mathrm{H}_{2} \mathrm{SO}_{4}\right)$ and $\mathrm{HNO}_{3}\left(w \mathrm{HNO}_{3}\right)$ in the liquid stratospheric aerosol are simulated (Carslaw et al., 1995b).

With the aid of the Henry coefficients $\left(k_{H}\right.$ in mol kg ${ }^{-1} \mathrm{~mol}^{-1}$, which mainly depend on the composition of the liquid aerosol, see Carslaw et al., 1997), the solubilities of $\mathrm{HCl}, \mathrm{HBr}$ (parameterisation from Luo et al., 1995), $\mathrm{HOCl}$ (Huthwelker et al., 1995) and HOBr (Hanson and Ravishankara, 1995) are calculated. With these solubilities it is possible to calculate the mass fractions of $\mathrm{HCl}(w \mathrm{HCl}), \mathrm{HBr}(w \mathrm{HBr}), \mathrm{HOCl}(w \mathrm{HOCl})$, $\mathrm{HOBr}(w \mathrm{HOBr})\left(\right.$ in $\left.\mathrm{kg} \mathrm{kg}^{-1}\right)$ in the liquid stratospheric aerosol. The mass fraction of $\mathrm{H}_{2} \mathrm{O}$ is 1.0 minus the calculated total mass fraction of the other constituents.

- The third step is the calculation of the mixing ratios (to dry air) of the substances in liquid phase $\left(\mathrm{H}_{2} \mathrm{SO}_{4}\right.$ (liq), $\mathrm{HNO}_{3}$ (liq), $\mathrm{H}_{2} \mathrm{O}$ (liq), $\mathrm{HCl}($ liq), $\mathrm{HBr}$ (liq), $\mathrm{HOCl}($ liq), $\mathrm{HOBr}\left(\right.$ liq) in $\mathrm{mol}\left(\right.$ substance) $\mathrm{mol}^{-1}$ (dry air)). It is assumed that the total stratospheric $\mathrm{H}_{2} \mathrm{SO}_{4}$ is liquid $\left(\mathrm{H}_{2} \mathrm{SO}_{4}(\mathrm{liq})\right)$. The mixing ratios of the other liquid substances are than calculated in relation to $\mathrm{H}_{2} \mathrm{SO}_{4}$ (liq).

For example $\mathrm{H}_{2} \mathrm{O}$ (liq) (amount of liquid $\mathrm{H}_{2} \mathrm{O}$ in mol $\mathrm{mol}^{-1}$ (dry air)) is calculated through:

$\mathrm{H}_{2} \mathrm{O}($ liq $)=\frac{w \mathrm{H}_{2} \mathrm{O} \cdot M_{\mathrm{H}_{2} \mathrm{SO}_{4}} \cdot \mathrm{H}_{2} \mathrm{SO}_{4}(\text { liq })}{M_{\mathrm{H}_{2} \mathrm{O}} \cdot w \mathrm{H}_{2} \mathrm{SO}_{4}}$

with $M_{\mathrm{H}_{2} \mathrm{O}}$ and $M_{\mathrm{H}_{2} \mathrm{SO}_{4}}$ being the molar masses of $\mathrm{H}_{2} \mathrm{O}$ and $\mathrm{H}_{2} \mathrm{SO}_{4}$, respectively (for constants see Table 1).

\subsection{The parameterisation of NAT particles}

For the formation of NAT particles (type 1a PSC) two different parameterisations exist. The first one is based on an instantaneous thermodynamical approach from Hanson and Mauersberger (1988) and is referred to hereafter as "thermodynamic NAT parameterisation". The second one considers the growth of the NAT particles with the aid of a surface growth factor based on Carslaw et al. (2002) and is called in the following as "kinetic growth NAT parameterisation".
The thermodynamic NAT parameterisation has been implemented in EMAC by Buchholz (2005), the kinetic growth parameterisation has been new implemented.

\subsubsection{Thermodynamic NAT parameterisation}

The formation of solid PSC particles using the thermodynamic NAT parameterisation is based on the assumption that NAT only forms via heterogeneous formation of NAT on ice particles (see Sect. 1.2) and ice forms at supersaturation (see Sect. 1.3). For this approach a so called "phase concept" in the submodel PSC exists.

The formation of PSC particles is controlled through the model variable phase. It describes if the formation conditions of STS, NAT and ice exist or not:

- phase $=0 \rightarrow$ no formation conditions for PSC,

- phase $=1 \rightarrow$ formation conditions for STS,

- phase $=2 \rightarrow$ formation conditions for STS and NAT,

- phase $=3 \rightarrow$ formation conditions for STS, NAT and ice.

Outside a defined PSC region the variable phase is 0 , within this region phase is always 1,2 or 3 , i.e., only in this region it is possible to form PSC. The boundaries (latitude, lower and upper altitute limits) of the PSC region can be determined via the PSC submodel namelists (see Sect. 4).

The heterogeneous NAT formation on ice particles is the underlying assumption for the phase concept (Carslaw et al., 1998). If the temperature drops below $T_{\text {ice }}$, ice particles are formed and it is also possible to form NAT. The variable phase will be set to 3 if the total partial pressure of $\mathrm{H}_{2} \mathrm{O}\left(e_{\mathrm{H}_{2} \mathrm{O}_{\text {(total }}}\right.$ in $\mathrm{Pa}$, the sum of gas, liquid and solid $\left.\mathrm{H}_{2} \mathrm{O}\right)$ is greater than the saturation vapour pressure of $\mathrm{H}_{2} \mathrm{O}$ over ice $\left(E_{\mathrm{H}_{2} \mathrm{O}}^{\mathrm{ice}}\right.$ in $\mathrm{Pa}$, calculated according to Marti and Mauersberger, 1993).

After melting of ice, the NAT existence is further possible as long as the conditions for NAT formation are given $\left(T \leqslant T_{\mathrm{NAT}}\right)$. The variable phase will be set to 2 if the total partial pressure of $\mathrm{HNO}_{3}\left(e_{\mathrm{HNO}_{3} \text { (total) }}\right.$ in $\mathrm{Pa}$, the sum of gas, liquid and solid $\mathrm{HNO}_{3}$ ) is greater than the saturation vapour pressure of $\mathrm{HNO}_{3}$ over NAT $\left(E_{\mathrm{HNO}_{3}}^{\mathrm{NAT}}\right.$ in Pa, calculated according to Hanson and Mauersberger, 1988).

Using the thermodynamic NAT parameterisation the homogeneous NAT formation (see Sect. 1.2) is only possible if the parameter LHomNucNAT from the PSC submodel namelists is set to true (see Sect. 4). With the default setup it is not possible to change phase from 1 to 2 .

With the help of the PSC submodel namelists, it is also possible to set supersaturations for ice and NAT formation (see Sect. 4).

With the aid of $e_{\mathrm{HNO}_{3}(\text { total })}$ and $E_{\mathrm{HNO}_{3}}^{\mathrm{NAT}}$, depending on temperature and on the mixing ratio of $\mathrm{HNO}_{3}$, it is possible 
to simulate the mixing ratio of $\mathrm{HNO}_{3}$ contained in NAT $\left(\mathrm{HNO}_{3}(\mathrm{NAT})\right.$ in $\left.\mathrm{mol} \mathrm{mol}^{-1}\right)$ :

$\mathrm{HNO}_{3}(\mathrm{NAT})=\frac{\left(e_{\mathrm{HNO}_{3(\text { total }}}-E_{\mathrm{HNO}_{3}}^{\mathrm{NAT}}\right)}{p}$

with $p$ the ambient pressure (in Pa). It takes place, if phase is set to 2 or to 3 .

\subsubsection{Kinetic growth NAT parameterisation}

\section{Growth and contraction of NAT particles with the aid of a surface growth factor}

The kinetic growth NAT parameterisation assumes that the homogeneous NAT formation starts from STS. The phase concept is therefore not required in this approach.

NAT particles initially form with a radius of $0.1 \mu \mathrm{m}$ and a particle number density of $1.5 \times 10^{-5}$ particles $\mathrm{cm}^{-3}$ when the temperature is below $T_{\mathrm{NAT}}$ (Hanson and Mauersberger, 1988). With the help of the PSC submodel namelists, it is also possible to set necessary supersaturations for the initial NAT formation (see Sect. 4).

After initialisation, the kinetic growth NAT parameterisation uses a surface growth factor $\left(G\right.$ in $\left.\mathrm{m}^{2} \mathrm{~s}^{-1}\right)$ based on Carslaw et al. (2002) to calculate the growth and contraction of NAT. The time-related growth of the NAT particles is a function of this surface growth factor and of the particle radius $(r$ in $\mathrm{m})$ :

$\frac{d r}{d t}=\frac{G}{r}$

with

$G=\frac{D_{\mathrm{HNO}_{3}}^{*} M_{\mathrm{NAT}}}{\rho_{\mathrm{NAT}} R_{\mathrm{gas}} T}\left(e_{\mathrm{HNO}_{3}}-E_{\mathrm{HNO}_{3}}^{\mathrm{NAT}}\right)$

This equation describes the dependence of the surface growth factor on the temperature, the difference between the partial $\mathrm{HNO}_{3}$ vapour pressure $\left(e_{\mathrm{HNO}_{3}}\right)$ and the saturation vapour pressure of $\mathrm{HNO}_{3}$ over NAT $\left(E_{\mathrm{HNO}_{3}}^{\mathrm{NAT}}\right)$, as well as from the diffusion coefficient of $\mathrm{HNO}_{3}$ in air $\left(D_{\mathrm{HNO}_{3}}^{*}\right.$ in $\left.\mathrm{m}^{2} \mathrm{~s}^{-1}\right)$. The molar mass of NAT $\left(M_{\mathrm{NAT}}\right)$, the universal gas constant $\left(R_{\text {gas }}\right)$ and the crystal mass density of NAT $\left(\rho_{\mathrm{NAT}}\right)$ are constants. For positive $G$, the radii of the NAT particles increase through condensation of $\mathrm{HNO}_{3}$. For negative $G$, the particles contract through evaporation.

$D_{\mathrm{HNO}_{3}}^{*}$ is calculated to account for mass transfer non continuum effects for particles with sizes similar to the mean free path (Carslaw et al., 2002):

$D_{\mathrm{HNO}_{3}}^{*}=\frac{D_{\mathrm{HNO}_{3}}}{1+4 D_{\mathrm{HNO}_{3}} /\left(v_{\mathrm{HNO}_{3}} r\right)}$

where $D_{\mathrm{HNO}_{3}}$ (in $\mathrm{m}^{2} \mathrm{~s}^{-1}$ ) is the diffusion coefficient of $\mathrm{HNO}_{3}$ in air and $v_{\mathrm{HNO}_{3}}$ (in $\mathrm{m} \mathrm{s}^{-1}$ ) is the mean molecular speed.

\section{Growth of NAT particles over size bins}

With the aid of the surface growth factor it is possible to simulate the growth and evaporation of NAT particles. For integration of this growth concept in EMAC, which is an Eulerian model, it is necessary to split the NAT particles into different size bins. In the kinetic growth NAT parameterisation of the submodel PSC consequently a separation into eight size bins is implemented (see Table 2). These are based on a PSC algorithm in the chemistry transport model (CTM) TM5 described by van den Broek et al. (2004).

For every size bin a minimum, a maximum and a mean radius $\left(r_{\mathrm{NAT}(\mathrm{bin})}\right.$ in $\left.\mu \mathrm{m}\right)$ exist, as well as a maximum number density (in particles $\mathrm{cm}^{-3}$ ). The separation of the size bins is based on observations by aircraft, performed in the Arctic winter 1999/2000 by Fahey et al. (2001). They observed a total number density of NAT particles of $2.3 \times$ $10^{-4}$ particles $\mathrm{cm}^{-3}$, with radii up to greater than $10 \mu \mathrm{m}$.

The mean radii of the eight size bins $\left(r_{\mathrm{NAT}(\mathrm{bin})}\right)$ used in the PSC submodel are $0.1 \mu \mathrm{m}, 0.6 \mu \mathrm{m}, 1.5 \mu \mathrm{m}, 4.0 \mu \mathrm{m}$, $7.5 \mu \mathrm{m}, 10.5 \mu \mathrm{m}, 14.0 \mu \mathrm{m}$ and $18.0 \mu \mathrm{m}$ (Table 2). The maximum number densities are $3.28 \times 10^{-5}$ particles $\mathrm{cm}^{-3}$ in the size bins $1-6 \quad\left(\frac{2.3 \times 10^{-4}}{7}\right.$ particles $\left.\mathrm{cm}^{-3}\right)$ and $1.64 \times 10^{-5}$ particles $\mathrm{cm}^{-3}$ in the size bins 7 and 8 $\left(\frac{3.28 \times 10^{-5}}{2}\right.$ particles $\left.\mathrm{cm}^{-3}\right)$. The measured distribution of NAT particles by Fahey et al. (2001, Fig. 4) is considered by the definition of the minimum and maximum radii of the sizebins (Table 2).

To use this size bin concept additional tracers have been defined in EMAC. The mixing ratio of $\mathrm{HNO}_{3}$ contained in NAT $\left(\mathrm{HNO}_{3}\right.$ (NAT)) had to be split up in eight tracers $\left(\mathrm{HNO}_{3}(\mathrm{NAT})_{(\text {bin })}\right.$ in $\mathrm{mol} \mathrm{mol}^{-1}$, one tracer per size bin) to ensure transport and diffusion for the NAT particles.

The distribution of the NAT particles to the size bins are calculated in a loop from size bin 1 to size bin 8 .

- In a first step the initial number density of NAT in the size bin $\left(N_{\mathrm{NAT}_{(\text {binini }}}\right)$ is calculated from the initial $\mathrm{HNO}_{3}(\mathrm{NAT})_{(\mathrm{bin}) \text { ini }}$ with the aid of the initial mass of one NAT particle $\left(m_{\mathrm{p}(\mathrm{bin}) \text { ini }}\right.$ in $\left.\mathrm{kg}\right)$ with the mean radius of this size bin $\left(r_{\mathrm{NAT}(\mathrm{bin})}\right)$ :

$N_{\mathrm{NAT}(\mathrm{bin}) \text { ini }}=\frac{\mathrm{HNO}_{3}(\mathrm{NAT})_{(\mathrm{bin}) \text { ini }} M_{\mathrm{NAT}}}{m_{\mathrm{p}(\mathrm{bin}) \text { ini }} N_{A}}$

with

$m_{\mathrm{p}(\mathrm{bin}) \text { ini }}=\frac{4}{3} \pi \rho_{\mathrm{NAT}} r_{\mathrm{NAT}(\mathrm{bin})}^{3}$

If in size bin 1 the mixing ration of $\mathrm{HNO}_{3}(\mathrm{NAT})_{(1)}$ is equal to zero and the temperature is below $T_{\mathrm{NAT}}$ (Hanson and Mauersberger, 1988), supersaturation can be adjusted via the PSC namelists) $N_{\mathrm{NAT}_{(1) \text { ini }}}$ will be set to $1.5 \times 10^{-5}$ particles $\mathrm{cm}^{-3}$. 
Table 2. The eight size bins in submodel PSC used for the kinetic growth NAT parameterisation.

\begin{tabular}{lllllllll}
\hline Size bin & 1 & 2 & 3 & \multicolumn{1}{l}{4} & \multicolumn{1}{l}{5} & \multicolumn{1}{l}{6} & \multicolumn{1}{l}{7} & \multicolumn{1}{l}{8} \\
\hline Minimum radius $(\mu \mathrm{m})$ & 0.0 & 0.2 & 1.0 & 2.0 & 6.0 & 9.0 & 12.0 & 16.0 \\
Maximum radius $(\mu \mathrm{m})$ & 0.2 & 1.0 & 2.0 & 6.0 & 9.0 & 12.0 & 16.0 & 20.0 \\
Mean radius $(\mu \mathrm{m})$ & 0.1 & 0.6 & 1.5 & 4.0 & 7.5 & 10.5 & 14.0 & 18.0 \\
Maximum number density & 3.28 & 3.28 & 3.28 & 3.28 & 3.28 & 3.28 & 1.64 & 1.64 \\
$\left(10^{-5}\right.$ particles cm $\left.{ }^{-3}\right)$ & & & & & & & & \\
\hline
\end{tabular}

- In a second step a new radius $\left(r_{\text {new(bin) }}\right)$ for the size bin is calculated with the aid of the integrated form of Eq. (3):

$$
r_{\text {new }(\text { bin })}=\sqrt{r_{\mathrm{NAT}(\mathrm{bin})}^{2}+2 G \Delta t}
$$

with the surface growth factor $G$ (Eq. 4) and $\Delta t$, the time step (in s).

With $r_{\text {new (bin) }}$ it is possible to calculate the new mass of one

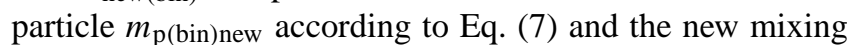
ratio of $\mathrm{HNO}_{3}$ contained in $\mathrm{NAT}\left(\mathrm{HNO}_{3}(\mathrm{NAT})_{(\text {bin)new }}\right)$ :

$$
\mathrm{HNO}_{3}(\mathrm{NAT})_{(\text {bin }) \text { new }}=\mathrm{HNO}_{3}(\mathrm{NAT})_{(\text {bin }) \text { ini }} \frac{m_{\mathrm{p}(\text { bin }) \text { new }}}{m_{\mathrm{p}(\text { bin }) \text { ini }}}
$$

The new number density for NAT particles of the current size bin $\left(N_{\mathrm{NAT}_{(\mathrm{bin})}}\right)$ with the corresponding mean radius is calculated with

$N_{\mathrm{NAT}(\text { bin })}=\frac{\mathrm{HNO}_{3}(\mathrm{NAT})_{(\text {bin }) \text { new }} M_{\mathrm{NAT}}}{r_{\mathrm{NAT}(\text { bin })} N_{A}}$

If $N_{\mathrm{NAT}_{\text {(bin) }}}$ is larger than the maximum number density of the current size bin, the overrun will be transferred to the next larger size bin by transformation into the corresponding number density of NAT particles with the mean radius of this larger size bin. The overrun is also considered in the calculation of $\mathrm{HNO}_{3}$ (NAT) (bin)new (Eq. 9).

After the loop over all size bins, it is possible to calculate the total $\mathrm{HNO}_{3}(\mathrm{NAT})$ as the sum of all $\mathrm{HNO}_{3}(\mathrm{NAT})_{(\text {bin) }}$ :

$\mathrm{HNO}_{3}(\mathrm{NAT})=\sum_{\text {bin }=1}^{8} \mathrm{HNO}_{3}(\mathrm{NAT})_{(\text {bin })}$

\subsection{The parameterisation of ice particles}

For the formation of ice particles (type 2 PSC) there is only one parameterisation in the submodel PSC. It is based on the thermodynamic approach of Marti and Mauersberger (1993).

If phase is set to 3 , the water fraction in ice particles $\left(\mathrm{H}_{2} \mathrm{O}\right.$ (ice) in $\left.\mathrm{mol} \mathrm{mol}^{-1}\right)$ is calculated as the difference of

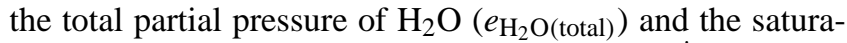
tion vapour pressure of $\mathrm{H}_{2} \mathrm{O}$ over ice particles $\left(E_{\mathrm{H}_{2} \mathrm{O}}^{\mathrm{ice}}\right)$, which depends on pressure and temperature:

$\mathrm{H}_{2} \mathrm{O}($ ice $)=\frac{\left(e_{\mathrm{H}_{2} \mathrm{O}(\text { total })}-E_{\mathrm{H}_{2} \mathrm{O}}^{\mathrm{ice}}\right)}{p}$

\subsection{The calculation of surfaces, number densities and mean radii of $\mathrm{PSC}$ particles}

For the calculation of the reaction coefficients $(\kappa)$ of the heterogeneous reactions (see Sect. 3.5), which take place on the surface of the solid PSC particles as well as on the surface of the liquid stratospheric aerosols (STS and SSA), it is necessary to calculate the total surface of liquid aerosols, NAT and ice particles.

\subsubsection{Surfaces and mean radii of liquid droplets}

In the parameterisation for liquid droplets after Carslaw et al. $(1995 \mathrm{~b})$ the total surface $\left(A_{\text {liq }}\right.$ in $\left.\mathrm{cm}^{2} \mathrm{~cm}^{-3}\right)$ and the mean radius $\left(r_{\text {liq }}\right.$ in $\mathrm{cm}$ ) are simulated for the calculation of the heterogeneous reaction coefficients.

To calculate $A_{\text {liq }}$, first the total mass of the liquid phase per air volume $\left(m_{\text {total }}\right.$ in $\left.\mathrm{g} \mathrm{cm}^{-3}\right)$ is calculated. After this, the computation of the mass density of the liquid phase (dens liq in $\mathrm{g} \mathrm{cm}^{-3}$ ) is possible. With the equation

$V_{\text {liq }}=\frac{m_{\text {total }}}{\text { dens }_{\text {liq }}}$

the total volume of the liquid droplets per air volume ( $V_{\text {liq }}$ in $\mathrm{cm}^{3} \mathrm{~cm}^{-3}$ ) is calculated and also $A_{\text {liq }}$ following Grainger et al. (1995):

$A_{\text {liq }}=8.406 V_{\text {liq }}^{0.751}$

The mean radius of the liquid aerosols $\left(r_{\text {liq }}\right)$ is calculated with the relation of the effective radius ( $\left.r_{\text {eff }}\right), V_{\text {liq }}$ and the proportion of $r_{\text {liq }}$ and $r_{\text {eff }}$ assuming a logarithmic Gaussian distribution with the following parameterisations after Grainger et al. (1995):

$$
\begin{aligned}
r_{\text {liq }} & =r_{\text {eff }} e^{-0.173} \\
\text { with } \quad r_{\text {eff }} & =0.357 V_{\text {liq }}^{0.249}
\end{aligned}
$$

$A_{\text {liq }}$ is used in the calculation of the heterogeneous reaction coefficients $(\kappa)$ on stratospheric liquid aerosols in Eq. (21).

\subsubsection{Total number density and mean radius of solid particles using the thermodynamic NAT parameterisation}

Using the thermodynamic NAT parameterisation, the total number density $\left(N_{\text {solid }}\right.$ in particles $\left.\mathrm{m}^{-3}\right)$ and the mean radius 
( $r_{\text {solid }}$ in $\mathrm{m}$ ) instead of the total surface of the solid particles are calculated.

With the help of $\mathrm{H}_{2} \mathrm{O}$ (ice) (Eq. 12) and $\mathrm{HNO}_{3}$ (NAT) (Eq. 2) the total mass of solid particles $\left(m_{\text {solid }}\right)$ as well as their total volume $\left(V_{\text {solid }}\right.$ in $\left.\mathrm{m}^{3}\right)$ is calculated. The total number density of the solid particles $\left(N_{\text {solid }}\right)$ is then:

$N_{\text {solid }}=\max \left(\frac{3 V_{\text {solid }}}{4 \pi r_{\min }^{3}}, N_{\max }\right)$

The minimum radius ( $r_{\min }$ in $\mathrm{m}$ ) is from the PSC submodel namelists (see Sect. 4). $N_{\text {solid }}$ is compared with a maximum number density $\left(N_{\max }\right)$, also determined in the PSC submodel namelists. If $N_{\text {solid }}$ is greater than $N_{\max }$, then $N_{\text {solid }}$ is set to $N_{\max }$ (if this is the case, $r_{\text {solid }}$ will be greater than $r_{\text {min }}$, see Eq. 18).

With the help of $N_{\text {solid }}$ the mean radius $\left(r_{\text {solid }}\right)$ is calculated:

$r_{\text {solid }}=\sqrt[3]{\frac{3 V_{\text {solid }}}{4 \pi N_{\text {solid }}}}$

Within the thermodynamic NAT parameterisation $N_{\text {solid }}$ and $r_{\text {solid }}$ are used for the calculation of the reaction coefficients $(\kappa)$ of heterogeneous reactions on the surface of ice and NAT particles (see Eq. 24). $N_{\text {solid }}$ is the sum of ice and NAT particles and $r_{\text {solid }}$ the mean radius of these solid particles.

\subsubsection{Total number density and mean radius of NAT and ice particles using the kinetic growth NAT parameterisation}

In contrast to the thermodynamic NAT approach, in the kinetic growth NAT parameterisation the number densities of $\operatorname{NAT}\left(N_{\mathrm{NAT}}\right)$ and ice particles $\left(N_{\text {ice }}\right.$ in particles $\left.\mathrm{m}^{-3}\right)$, as well as the mean radii of NAT particles $\left(r_{\mathrm{NAT}}\right)$ and ice particles ( $r_{\text {ice }}$ in $\mathrm{m}$ ) are used for the calculation of the heterogeneous reaction coefficients $(\kappa)$ on the surface of NAT (Eq. 25) and ice particles (Eq. 26).

The number density of NAT is calculated from the single number density in each size bin $\left(N_{\mathrm{NAT}_{\text {bin }}}\right)$ :

$N_{\mathrm{NAT}}=\sum_{\text {bin }=1}^{8} N_{\mathrm{NAT}(\mathrm{bin})}$

The mean NAT radius of all particles is calculated from the radii of each size bin $\left(r_{\mathrm{NAT}_{\text {bin }}}\right)$, weighted with $N_{\mathrm{NAT}}$ :

$r_{\mathrm{NAT}}=\sqrt{\left(\sum_{\text {bin }=1}^{8} N_{\mathrm{NAT}(\mathrm{bin})} \cdot r_{\mathrm{NAT}(\mathrm{bin})}^{2}\right) / N_{\mathrm{NAT}}}$

The number density of ice particles $\left(N_{\text {ice }}\right)$ and their radius ( $\left.r_{\text {ice }}\right)$ are defined in the same way as $N_{\text {solid }}$ (Eq. 17) and $r_{\text {solid }}$ (Eq. 18).

\subsection{The calculation of heterogeneous chemistry reaction coefficients}

The reaction coefficients for the heterogeneous reactions on PSCs (see Reactions R1-R11) are calculated in the PSC submodel. After calculation the reaction coefficients are delivered to the chemistry submodel MECCA1 (Sander et al., 2005). In MECCA1 the corresponding heterogeneous chemistry is simulated.

\subsubsection{Liquid droplets}

The second order heterogeneous reaction coefficient ${ }^{1}(\kappa$ in $\mathrm{cm}^{3} \mathrm{~s}^{-1}$ ) for liquid stratospheric aerosol (STS and SSA) is calculated in a first step as a heterogeneous reaction coefficient of first $\operatorname{order}^{2}$ ( $\kappa^{I}$ in $1 \mathrm{~s}^{-1}$, Hanson et al., 1996):

$\kappa^{I}=\frac{\gamma_{\text {liq }} \cdot c_{\text {bar }} \cdot A_{\text {liq }}}{4}$

with $\gamma_{\text {liq }}$ the reaction probability on liquid droplets, $A_{\text {liq }}$ the

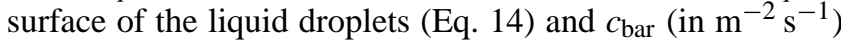
an auxiliary variable (Eq. 22). In the majority of heterogeneous reactions $\gamma_{\text {liq }}$ depends on the radius of the liquid aerosols and on the mixing ratios of the substances in the gas phase involved in the reaction, as well on the temperatures. For the specific heterogeneous reaction $\gamma$ is calculated after Carslaw et al. (1995a,b), Luo et al. (1995), Hanson and Ravishankara (1994) and Hanson et al. (1996).

The variable $c_{\text {bar }}$ depends on a constant and on the temperature:

$c_{\text {bar }}=c \sqrt{T}$

According to the specific heterogeneous reaction, the constant $c$ is in the range between 1221.4 (Reaction R6) and 1616.0 (Reaction R11). For more details see Carslaw et al. (1995b).

The heterogeneous reactions (Reactions R1-R11) are bimolecular reactions, with one educt in gas phase and one educt in liquid phase. To get $\kappa$ from $\kappa^{I}$ it is necessary to divide $\kappa^{I}$ by the gas phase concentration of the substance in liquid phase (respectively solid phase by NAT and ice, see below). For example for Reaction:

$\mathrm{N}_{2} \mathrm{O}_{5}(\mathrm{~g})+\mathrm{H}_{2} \mathrm{O}(\mathrm{l}, \mathrm{s}) \stackrel{\text { het }}{\longrightarrow} 2 \mathrm{HNO}_{3}(\mathrm{l}, \mathrm{s})$

$\kappa$ is calculated as:

$\kappa=\frac{\kappa^{I}}{\left[\mathrm{H}_{2} \mathrm{O}\right]}$

This calculation is possible as the concentration of $\mathrm{H}_{2} \mathrm{O}$ is much higher than the concentration of $\mathrm{N}_{2} \mathrm{O}_{5}$ and the concentration of $\mathrm{H}_{2} \mathrm{O}$ is more or less independent of the reaction. The concentration of $\mathrm{N}_{2} \mathrm{O}_{5}$ is therefore the limiting factor.

\footnotetext{
$1_{\text {true for bimolecular reactions }}$

${ }^{2}$ true for monomolecular reactions
} 
Table 3. Reaction probabilities $\gamma$ for heterogeneous reactions on ice particles $\left(\gamma_{\text {ice }}\right)$ and on NAT particles $\left(\gamma_{\mathrm{NAT}}\right)$ in the submodel PSC. Not in italics: $\gamma$ from laboratory studies, valid for the temperature range in parentheses (Sander et al., 2003, 2006). In italics: $\gamma$ as used in the original code of the "Mainz Stratospheric Box Model" (Carslaw et al., 1994).

\begin{tabular}{lll}
\hline Heterogeneous reaction & $\begin{array}{l}\text { on ice particles } \\
\left(\gamma_{\text {ice }}\right)\end{array}$ & $\begin{array}{l}\text { on NAT particles } \\
\left(\gamma_{\mathrm{NAT}}\right)\end{array}$ \\
\hline$(\mathrm{R} 1) \mathrm{N}_{2} \mathrm{O}_{5}(\mathrm{~g})+\mathrm{H}_{2} \mathrm{O}(\mathrm{s})$ & $0.02(188-195 \mathrm{~K})$ & $4 \times 10^{-4}(200 \mathrm{~K})$ \\
$(\mathrm{R} 2) \mathrm{N}_{2} \mathrm{O}_{5}(\mathrm{~g})+\mathrm{HCl}(\mathrm{s})$ & $0.03(190-220 \mathrm{~K})$ & $0.003(200 \mathrm{~K})$ \\
$(\mathrm{R} 3) \mathrm{ClONO}_{2}(\mathrm{~g})+\mathrm{H}_{2} \mathrm{O}(\mathrm{s})$ & $0.3(180-200 \mathrm{~K})$ & $0.004(200-202 \mathrm{~K})$ \\
$(\mathrm{R} 4) \mathrm{ClONO}_{2}(\mathrm{~g})+\mathrm{HCl}(\mathrm{s})$ & $0.3(180-200 \mathrm{~K})$ & $0.2(185-210 \mathrm{~K})$ \\
$(\mathrm{R} 5) \mathrm{ClONO}_{2}(\mathrm{~g})+\mathrm{HBr}(\mathrm{s})$ & $0.3(200 \mathrm{~K})$ & $0.3(200 \mathrm{~K})$ \\
$(\mathrm{R} 6) \mathrm{BrONO}_{2}(\mathrm{~g})+\mathrm{H}_{2} \mathrm{O}(\mathrm{s})$ & $0.3(190-200 \mathrm{~K})$ & 0.001 \\
$(\mathrm{R} 7) \mathrm{BrONO}_{2}(\mathrm{~g})+\mathrm{HCl}(\mathrm{s})$ & 0.3 & 0.3 \\
$(\mathrm{R} 8) \mathrm{HOCl}(\mathrm{g})+\mathrm{HCl}(\mathrm{s})$ & $0.2(195-200 \mathrm{~K})$ & $0.1(195-200 \mathrm{~K})$ \\
$(\mathrm{R} 9) \mathrm{HOCl}(\mathrm{g})+\mathrm{HBr}(\mathrm{s})$ & $0.3(189 \mathrm{~K})$ & 0.3 \\
$(\mathrm{R} 10) \mathrm{HOBr}(\mathrm{g}+\mathrm{HCl}(\mathrm{s})$ & $0.3(180-228 \mathrm{~K})$ & 0.1 \\
$(\mathrm{R} 11) \mathrm{HOBr}(\mathrm{g})+\mathrm{HBr}(\mathrm{s})$ & $0.1(228 \mathrm{~K})$ & 0.1 \\
\hline
\end{tabular}

\subsubsection{Solid NAT and ice particles using the thermodynamic NAT parameterisation}

Using the thermodynamic PSC parameterisation the first step of the calculation of $\kappa$ on NAT and ice particles is to calculate $\kappa^{I}$ with $N_{\text {solid }}$ and $r_{\text {solid }}$ :

$\kappa^{I}(r)=\frac{4.56 \times 10^{4} \gamma \sqrt{\frac{T}{M_{\mathrm{A}}}} r_{\text {solid }}^{2} N_{\text {solid }}}{1+3.3 \times 10^{4} \gamma r_{\text {solid }} \frac{p}{T}}$

with $M_{\mathrm{A}}$ the molecular mass of substance A (educt of heterogeneous reaction in gas phase, in $\left.\mathrm{g} \mathrm{mol}^{-1}\right), T$ the temperature (in $\mathrm{K}$ ), $p$ the pressure (in $\mathrm{hPa}$ ), $r_{\text {solid }}$ the radius of solid particles (in cm, see Eq. 18), $N_{\text {solid }}$ the number density of solid particles (Eq. 17) and $\gamma$ the reaction probability (see Table 3). Two calculations are performed, the first one calculates $\kappa^{I}$ on ice particles using $\gamma_{\text {ice }}$, the second one calculates $\kappa^{I}$ on NAT particles using $\gamma_{\text {NAT }}$. For more details on Eq. (24) see Müller (1994) and Turco et al. (1989).

To get $\kappa$ for the specific heterogeneous reaction, it is necessary to divide $\kappa^{I}$ (see Eq. 23) by the gas phase concentration of the substance contained in solid phase as educt in the heterogeneous reaction.

The reaction probabilities $(\gamma)$ of the reactions on NAT $\left(\gamma_{\mathrm{NAT}}\right)$ and ice particles $\left(\gamma_{\text {ice }}\right)$ used in the PSC submodel are described in Table 3. Most of the reaction probabilities are from Sander et al. (2003, 2006). The others are transferred from the original code of the PSC submodel which is based on the "Mainz Stratospheric Box Model" (Carslaw et al., 1994).

\subsubsection{Solid NAT and ice particles using the kinetic growth NAT parameterisation}

Using the kinetic growth NAT parameterisation, the heterogeneous reaction coefficients (second order, $\kappa$ ) for NAT particles are also calculated with Eq. (24). In this case neither $N_{\text {solid }}$ nor $r_{\text {solid }}$ are used, but $N_{\mathrm{NAT}}$ and $r_{\mathrm{NAT}}$. The calculation of $\kappa^{I}$ on NAT particles is then:

$k^{I}(r)=\frac{4.56 \times 10^{4} \gamma \gamma_{\mathrm{NAT}} \sqrt{\frac{T}{M_{\mathrm{A}}}} r_{\mathrm{NAT}}^{2} N_{\mathrm{NAT}}}{1+3.3 \times 10^{4} \gamma r_{\mathrm{NAT}} \frac{p}{T}}$

with $r_{\text {NAT }}$ the mean radius of NAT (in cm, Eq. 20), $N_{\text {NAT }}$ the number density of NAT (Eq. 19) and $\gamma_{\text {NAT }}$ the reaction probability on NAT (Table 3 ).

The calculation of $\kappa^{I}$ on ice particles uses $N_{\text {ice }}$ and $r_{\text {ice }}$ instead of $N_{\text {solid }}$ and $r_{\text {solid }}$ in Eq. (24):

$k^{I}(r)=\frac{4.56 \times 10^{4} \gamma_{\text {ice }} \sqrt{\frac{T}{M_{\mathrm{A}}}} r_{\text {ice }}^{2} N_{\text {ice }}}{1+3.3 \times 10^{4} \gamma r_{\text {ice }} \frac{p}{T}}$

with $r_{\text {ice }}$ the mean radius of ice particles (in $\mathrm{cm}$ ), $N_{\text {ice }}$ the number density of ice particles and $\gamma_{\text {ice }}$ the reaction probability on ice particles (Table 3 ).

In order to get $\kappa$ for the specific heterogeneous reaction, it is necessary to divide $\kappa^{I}$ (see Eq. 23) by the gas phase concentration of the substance presented in solid phase as educt in the heterogeneous reaction.

\subsection{The sedimentation of PSC-particles}

Depending on the applied PSC parameterisation the calculation of sedimentation is performed for solid particles (thermodynamic NAT parameterisation) or for NAT and ice particles (kinetic growth NAT parameterisation). In each case the sedimentation can be separated into different parts.

After the calculation of the sedimentation velocity of the PSC particles, the range of the sedimentation path during one time step is calculated. Thereafter the change of mass fraction of the PSC particles per time step and grid box, as well as the changes of $\mathrm{H}_{2} \mathrm{O}$ and $\mathrm{HNO}_{3}$ in the gas phase are determined.

\subsubsection{Calculation of the sedimentation velocity}

\section{Sedimentation velocity using the thermodynamic NAT parameterisation}

Using the thermodynamic NAT parameterisation the sedimentation velocity is calculated for solid particles ( $v_{\text {sed(solid) }}$ in $\mathrm{m} \mathrm{s}^{-1}$ ) with the parameterisation of Waibel (1997). In this parameterisation in a first step the calculation of an auxiliary velocity $\left(v_{\mathrm{y}}\right.$ in $\left.\mathrm{m} \mathrm{s}^{-1}\right)$ takes place:

$v_{\mathrm{y}}=\frac{g \rho_{\text {ice }} r_{\text {solid }}^{2}}{4.5 \cdot \eta T}$ 
with $g$ the acceleration of gravity, $\rho_{\text {ice }}$ the density of ice particles, $r_{\text {solid }}$ the mean radius of solid particles (in $\mathrm{m}$ ) and a factor $\eta\left(6.45 \times 10^{-8} \mathrm{~kg} \mathrm{~m}^{-1} \mathrm{~s}^{-1} \mathrm{~K}^{-1}\right)$. The sedimentation velocity for solid particles is calculated in a second step from $v_{\mathrm{y}}$ (in $\mathrm{m} \mathrm{s}^{-1}$ ) and the variable $\operatorname{val}_{\mathrm{x}}$ (dimensionless):

$v_{\text {sed(solid) }}=0.893 v_{\mathrm{y}}$ val $_{\mathrm{x}}$

with

$\operatorname{val}_{\mathrm{x}}=1+\frac{\alpha_{1} T}{p r_{\text {solid }}}+\frac{\alpha_{2} T e^{\frac{-p r_{\text {solid }}}{\alpha_{3} T}}}{p r_{\text {solid }}}$

and $p$ the pressure (in $\mathrm{Pa}$ ) as well as the auxiliary variables $\alpha_{1}=1.49 \times 10^{-5} \mathrm{~m} \mathrm{~Pa} \mathrm{~K}^{-1}, \alpha_{2}=5.02 \times 10^{-6} \mathrm{~m} \mathrm{~Pa} \mathrm{~K}^{-1}$ and $\alpha_{3}=2.64 \times 10^{-5} \mathrm{~m} \mathrm{~Pa} \mathrm{~K}^{-1}$.

\section{Sedimentation velocity using the kinetic growth NAT parameterisation}

Using the kinetic growth PSC parameterisation, the sedimentation velocity is not calculated for solid particles but for NAT and ice particles. The calculation of the sedimentation velocity for ice particles $\left(v_{\text {sed(ice) }}\right.$ in $\left.\mathrm{m} \mathrm{s}^{-1}\right)$ is performed with $r_{\text {ice }}$ using the parameterisation of Waibel (1997) described in the Eqs. (27)-(29).

The sedimentation velocity for NAT particles $\left(v_{\text {sed(NAT) }}\right.$ in $\mathrm{m} \mathrm{s}^{-1}$ ) is based on Carslaw et al. (2002). The sedimentation velocity is calculated for every NAT size bin $\left(v_{\left.\text {sed(NAT })_{(b i n)}\right)}\right.$. $v_{\text {sed(NAT) }}$ bin depends on the mean radius of the NAT size bin $\left(r_{\mathrm{NAT}(\mathrm{bin})}\right)$ and on a sedimentation factor $\left(S\right.$ in $\left.\mathrm{ms}^{-1}\right)$ :

$v_{\mathrm{sed}(\mathrm{NAT})_{(\mathrm{bin})}}=S r_{\mathrm{NAT}(\mathrm{bin})}^{2}$

with

$S=\frac{2 g \rho_{\mathrm{NAT}} C_{\mathrm{c}}}{9 \eta_{\mathrm{a}}}$

with $\rho_{\text {NAT }}$ the crystal mass density of NAT, $C_{\mathrm{c}}$ the "Cunningham slip flow correction factor" (dimensionless) and $\eta_{\mathrm{a}}$ the viscosity of air (in $\mathrm{g} \mathrm{ms}^{-1}$ ).

The correction factor $C_{\mathrm{c}}$ is calculated by:

$C_{\mathrm{c}}=1+\frac{l_{\mathrm{HNO}_{3}}}{r_{\mathrm{NAT}(\text { bin })}}\left[1.257+0.4 e^{\left(\frac{-1.1 r_{\mathrm{NAT}_{\text {bin }}}}{l_{\mathrm{HNO}_{3}}}\right)}\right]$

with $l_{\mathrm{HNO}_{3}}$ the mean free path of the $\mathrm{HNO}_{3}$-particles (in m) (Carslaw et al., 2002).

\subsubsection{Calculation of the range of the sedimentation path (sedimentation step)}

The vertical distance of a falling particle per time step is calculated by using the sedimentation velocity. As the vertical coordinate is pressure, this sedimentation step is a pressure difference (SedStep in $\mathrm{Pa}$ ).

SedStep $=\frac{g M_{\mathrm{air}} p v_{\mathrm{sed}} \Delta t}{R_{\mathrm{gas}} T}$

with $M_{\text {air }}$ the molar mass of air, $p$ the pressure (in $\mathrm{Pa}$ ) and $\Delta t$ the time step (in s).

SedStep is calculated for solid particles $\left(\right.$ SedStep $\left._{\text {solid }}\right)$ by using the thermodynamic NAT parameterisation and for ice particles $\left(\right.$ SedStep $\left._{\text {ice }}\right)$ as well as for NAT particles with respect to every size bin (SedStep NAT(bin) $_{\text {(bin }}$ when using the kinetic growth NAT parameterisation.

\subsubsection{Calculation of the changes in gas phase $\mathrm{H}_{2} \mathrm{O}$ and $\mathrm{HNO}_{3}$ due to sedimentation}

With the help of SedStep the changes of the mixing ratios of $\mathrm{H}_{2} \mathrm{O}$ and $\mathrm{HNO}_{3}$ in gas phase due to ice or NAT sedimentation are calculated. There are three different sedimentation schemes in EMAC available: the "Simple Upwind Scheme", the "Walcek2000 Scheme" (Walcek, 2000) and the "Trapezoid Scheme" (Buchholz, 2005). In the PSC submodel namelists (see Sect. 4) it is possible to choose one of it.

For example, using the "Simple Upwind Scheme" and the kinetic growth parameterisation the change of $\mathrm{HNO}_{3}$ is calculated for every size bin $\left(\mathrm{HNO}_{3(\operatorname{chg}(\operatorname{bin}, \mathrm{k}))}\right)$ :

$$
\begin{aligned}
\mathrm{HNO}_{3(\operatorname{chg}(\mathrm{bin}, \mathrm{k}))}= & \frac{\mathrm{HNO}_{3(\mathrm{bin}, \mathrm{k}-1)} \operatorname{SedStep}_{\mathrm{NAT}(\mathrm{bin}, \mathrm{k}-1)}}{p_{\mathrm{bot}(k)}-p_{\operatorname{top}(k)}} \\
& -\frac{\mathrm{HNO}_{3(\mathrm{bin}, k)} \operatorname{SedStep} p_{\mathrm{NAT}(\mathrm{bin}, k)}}{p_{\mathrm{bot}(k)}-p_{\mathrm{top}(k)}}
\end{aligned}
$$

$p_{\text {bot }(k)}$ and $p_{\text {top }(k)}$ are the pressures at the top and the bottom of the relevant grid box $k(k-1$ means the grid box above

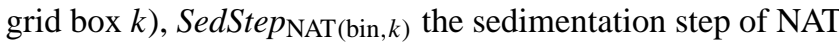
and $\mathrm{HNO}_{3(\text { bin, } k \text { ) }}$ the $\mathrm{HNO}_{3}$ mixing ratio of the current size bin in this grid box. The total change in $\mathrm{HNO}_{3}$ is the sum over all size bins:

$\mathrm{HNO}_{3(\operatorname{chg}(k))}=\sum_{\text {bin }=1}^{8} \mathrm{HNO}_{3(\operatorname{chg}(\operatorname{bin}, k))}$

The new $\mathrm{HNO}_{3}$ mixing ratio is calculated as:

$\mathrm{HNO}_{3(\text { new }(k))}=\mathrm{HNO}_{3(\operatorname{old}(k))}+\mathrm{HNO}_{3(\operatorname{chg}(k))}$

For the changes in $\left.\mathrm{H}_{2} \mathrm{O}\left(\mathrm{H}_{2} \mathrm{O}_{({ }} \operatorname{chg}_{(k)}\right)\right)$ the same calculations are performed, but with the sedimentation step of ice particles (SedStep ice).

Using the thermodynamic NAT parameterisation the changes of $\mathrm{H}_{2} \mathrm{O}$ and $\mathrm{HNO}_{3}$ are calculated with the sedimentation step of solid particles (SedStep solid $_{\text {). }}$.

The "Walcek2000 Scheme" and the "Trapezoid Scheme", as well as an assessment of the three sedimentation schemes are described in Buchholz (2005). The "Trapezoid Scheme" 
Table 4. The PSC Submodel CTRL and CPL namelists in the namelist file psc.nml, which is part of the MESSy user interface. The settings have been used for the simulation which results are presented in Sect. 5 .

\begin{tabular}{|c|c|}
\hline$\& C T R L$ & \\
\hline KinPar $=\mathrm{T}$ & switch for the kinetic growth NAT parameterisation (True/False) \\
\hline LAdvectIceNat $=\mathrm{F}$ & $\begin{array}{l}\text { influence of the advection to the formation of ice and NAT (True/False) } \\
\text { with KinPar }=T \rightarrow \text { only influence to the formation of ice }\end{array}$ \\
\hline LHomNucNAT $=\mathrm{F}$ & $\begin{array}{l}\text { homogen NAT-nucleation? (True/False) } \\
\text { with } \operatorname{KinPar}=T \rightarrow \text { irrelevant }\end{array}$ \\
\hline NatFormThreshold $=-3.0$ & supercooling for initialisation of NAT in K \\
\hline $\min K h e t=0.0$ & minimal reaction rate for the heterogeneous reactions in $\mathrm{cm}^{3} \mathrm{~s}^{-1}$ \\
\hline $\operatorname{maxKhet}=1.0 \times 10^{-13}$ & maximal reaction rate for the heterogeneous reactions in $\mathrm{cm}^{3} \mathrm{~s}^{-1}$ \\
\hline SupSatIce $=1.5$ & supercooling in percentage of $\mathrm{H}_{2} \mathrm{O}$ partial pressure \\
\hline$r_{\min }=1.0 \times 10^{-7}$ & $\begin{array}{l}\text { with } \operatorname{KinPar}=F \rightarrow \text { minimal radius of solid particles }\left(r_{\text {solid }}\right) \text { in } \mathrm{m} \\
\text { with } \operatorname{KinPar}=T \rightarrow \text { minimal radius of ice particles }\left(r_{\text {ice }}\right) \text { in } \mathrm{m}\end{array}$ \\
\hline$N_{\max }=42000$ & $\begin{array}{l}\text { with } \operatorname{KinPar}=F \rightarrow \text { maximal number density of solid particles in particles } \mathrm{m}^{-3} \\
\text { with } \operatorname{KinPar}=T \rightarrow \text { maximal number density of ice particles in particles } \mathrm{m}^{-3}\end{array}$ \\
\hline SedScheme $=1$ & $\begin{array}{l}\text { switch for sedimentation schemes: } \\
1=\text { simple upwind scheme } \\
2=\text { Walcek advection scheme } \\
3=\text { trapezoid scheme } \\
\text { else }=\text { no sedimentation }\end{array}$ \\
\hline \multicolumn{2}{|l|}{$\& C P L$} \\
\hline LCalcChem $=F$ & switch for computation of heterogeneous reaction rates in submodel PSC (True/False) \\
\hline TempShift $=0.0$ & internal change of temperature in $\mathrm{K}$ in submodel PSC \\
\hline$r_{\text {lat }}=-55.0,45.0$ & latitude limit of PSC region $(\mathrm{SH}, \mathrm{NH})$ \\
\hline$r_{\mathrm{lb}}=18000.0,18000.0$ & lower boundary of PSC region $[\mathrm{Pa}](\mathrm{SH}, \mathrm{NH})$ \\
\hline$r_{\mathrm{mb}}=14000.0,10000.0$ & middle boundary of PSC region $[\mathrm{Pa}](\mathrm{SH}, \mathrm{NH})$ \\
\hline$r_{\mathrm{ub}}=500.0,500.0$ & upper boundary of PSC region [Pa] $(\mathrm{SH}, \mathrm{NH})$ \\
\hline$l_{\text {feedback }}=T$ & feedback on dynamics \\
\hline
\end{tabular}

is implemented as "first order sedimentation scheme" in the SEDI submodel and therefore also described in Kerkweg et al. (2006a). Buchholz (2005) recommends the "Trapezoid Scheme" using the thermodynamic NAT parameterisation. But applying the kinetic growth NAT parameterisation Kirner (2008) recommends the "Simple Upwind Scheme".

\section{Namelists of the submodel PSC}

The two namelists of the PSC submodel are presented in Table 4. The CTRL namelist contains parameters for the internal control of the PSC submodel, the CPL namelist variables are important for coupling with other submodels. With these namelists it is possible to setup the submodel PSC with different parameters.

The most essential parameter in the PSC CTRL namelist is KinPar. It stands for the option using the described kinetic growth NAT parameterisation $(\operatorname{KinPar}=T)$ or the thermody- namic NAT parameterisation $(\operatorname{KinPar}=F)$. With the choice of KinPar some of the other parameters have different meanings.

If LAdvectIceNat is set to $T$ advected ice particles have influence on the formation of ice, i.e., if ice particles exist in a grid box, phase is set to 3 (see Sect. 3.2.1) and no supercooling (see below) is required to form ice particles. The same is valid for the NAT formation, i.e. if NAT particles already exist in a grid box, phase is set to 2 and no supercooling is required to form NAT. As the phase concept is not valid for NAT formation in the kinetic growth NAT parameterisation (KinPar $=T)$, LAdvectIceNat has in this case no influence.

The parameter LHomNucNAT has also no influence on the formation of NAT, if KinPar is set to $T$, as in the kinetic growth NAT parameterisation the homogeneous NAT formation is assumed. But if KinPar is set to $F$ and LHomNucNAT is set to $T$, homogeneous NAT formation is included in the thermodynamic NAT parameterisation. 

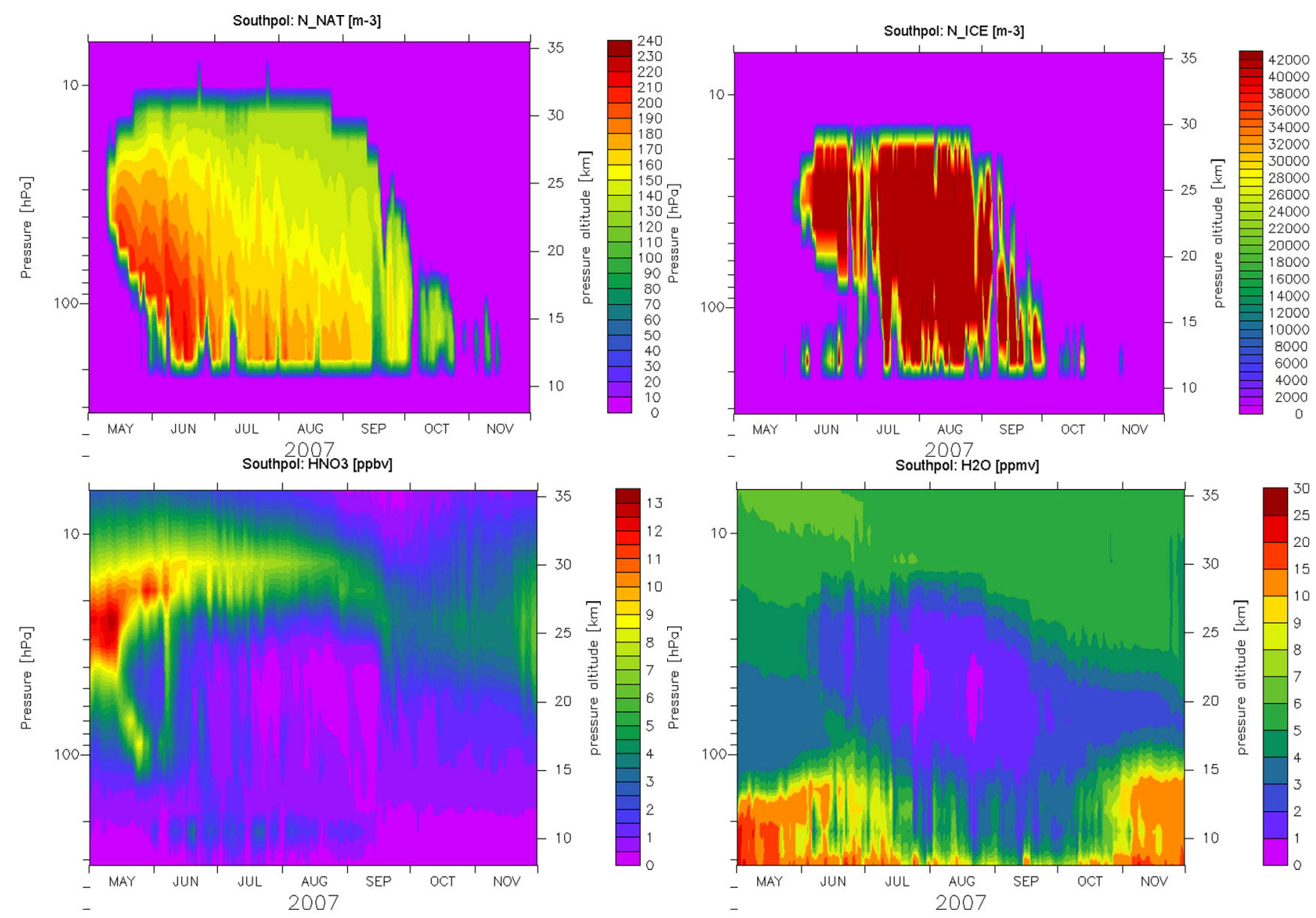

Fig. 1. Time series from May 2007 to November 2007 (zonally averaged polewards of $\left.87.9^{\circ} \mathrm{S}\right)$ : Number density of NAT particles $\left(N_{\mathrm{NAT}}\right.$ in particlesm ${ }^{-3}$, top left), number density of ice particles $\left(N_{\text {ice }}\right.$ in particlesm ${ }^{-3}$, top right), mixing ratio of $\mathrm{HNO}_{3}$ (in $\mathrm{nmolmol}^{-1}$, bottom left) and mixing ratio of $\mathrm{H}_{2} \mathrm{O}$ (in $\mu \mathrm{molmol}^{-1}$, bottom right).

For the homogenous NAT formation it is possible to set with NatFormThreshold a required supercooling (in K). This supercooling has an influence only, if LHomNucNAT is set to $T$, or if the kinetic growth NAT parameterisation is used. In any case NatFormThreshold is only needed for the first formation of NAT in a grid cell.

With minKhet and maxKhet it is possible to set minima and maxima for the heterogeneous reaction coefficients. For example, if the calculated coefficient is greater than maxKhet the heterogeneous reaction coefficient is limited by maxKhet. The values of minKhet and maxKhet are only relevant, if LCalcChem (see below) is set to $T$.

The parameter SupSatIce is responsible for the supersaturation for ice formation. It is denoted as a factor, for example a SupSatIce value of 1.5 means that the $\mathrm{H}_{2} \mathrm{O}$ partial pressure must be $50 \%$ higher as the $\mathrm{H}_{2} \mathrm{O}$ saturation pressure to form ice particles. The supersaturation should be reduced for coarse resolutions.

The parameters minimum radius $\left(r_{\min }\right)$ and maximum number density $\left(N_{\max }\right)$ are relevant for the calculation of the mean radius and number density of PSC particles. They are essential for the number density of solid particles using the thermodynamic NAT parameterisation or for ice particles using the kinetic growth NAT parameterisation, respectively (Eq. 17). The higher $N_{\max }$ is chosen, the lower is the mean radius and the sedimentation velocity of solid or ice particles, respectively.

With the parameter SedScheme the sedimentation scheme for the denitrification and dehydration is chosen. The simple upwind scheme is described in Sect. 3.6.3.

If the parameter LCalcChem in the PSC CPL namelist (Table 4) is set to $T$, the heterogeneous reaction coefficients are calculated in the submodel PSC. To transfer this reaction coefficients to the chemistry submodel MECCA 1 , it is required to set het_stream = "psc" in the CPL namelist of submodel MECCA1.

With the parameter TempShift it is possible to change the temperature in the submodel PSC. For example, if TempShift is set to -2.0 , the polar stratospheric clouds are calculated with temperatures $2.0 \mathrm{~K}$ lower that the model temperatures. This can be useful for sensitivity studies. 
The parameters $r_{\mathrm{lat}}, r_{\mathrm{lb}}, r_{\mathrm{mb}}$ and $r_{\mathrm{ub}}$ describe the boundaries of the PSC region. Only within this region the calculations concerning the polar stratospheric clouds take place. $r_{\text {lat }}$ (in degrees north) describes the borders of the PSC region in the Southern and Northern Hemisphere. $r_{\mathrm{lb}}$ and $r_{\mathrm{ub}}$ (in $\mathrm{Pa}$ ) are the lower and upper altitude boundaries of the Antarctic and Arctic PSC region. $r_{\mathrm{mb}}$ (in $\mathrm{Pa}$ ) describes the boundary below which the PSC region is calculated with the help of $T_{\text {ice }}$ and $T_{\mathrm{NAT}}$. Between $r_{\mathrm{lb}}$ and $r_{\mathrm{mb}}$ the PSC region is defined, if the condition $T_{\text {ice }} \leqslant T_{\mathrm{NAT}}$ is fulfilled.

With the help of the parameter $l_{\text {feedback }}$ it is possible to switch-off the dynamical-chemical feedback. In this case the total $\mathrm{HNO}_{3}$ vapour pressure $\left(e_{\mathrm{HNO}_{3(\text { total }}}\right.$ in $\left.\mathrm{Pa}\right)$ is described through a pre-defined climatology. This $\mathrm{HNO}_{3}$ climatology has to be imported, e.g. via the submodel OFFLEM (Kerkweg et al., 2006b).

\section{Results}

In Fig. 1 some results of an EMAC simulation (version 1.7, updated with the new version of submodel PSC) using the kinetic growth NAT parameterisation and the parameters of the PSC namelists in Table 4 are shown. During the Antarctic winter 2007 the formation of type 1a PSC polewards of $87.9^{\circ} \mathrm{S}$ begins mid May at altitudes between $20 \mathrm{hPa}$ and $40 \mathrm{hPa}$. After that the NAT particles exist in the maximum range from $180 \mathrm{hPa}$ to $13 \mathrm{hPa}$ and yield number densities of maximal 230 particles $\mathrm{m}^{-3}$. Through the sedimentation of NAT particles the denitrification takes place. Thus the mixing ratios of $\mathrm{HNO}_{3}$ decrease rapidly from May to July at altitudes of the existing type 1a PSC and obtain minima less than $0.5 \mathrm{nmol} \mathrm{mol}^{-1}$.

The formation of type 2 PSC starts at the beginning of June and therefore later as type 1a PSC. In the following time the ice particles exist in the maximum range from $180 \mathrm{hPa}$ to $18 \mathrm{hPa}$ and reach number densities of maximal 42000 particles $\mathrm{m}^{-3}$. Through the sedimentation of ice particles the dehydration takes place in the stratosphere. The mixing ratios of $\mathrm{H}_{2} \mathrm{O}$ rapidly decrease from June to August at altitudes with existing ice particles and obtain minima less than $1.0 \mu \mathrm{mol} \mathrm{mol}^{-1}$.

More results including a detailed evaluation of the effects of the thermodynamic and kinetic growth NAT parameterisation on the simulated chemistry will be published by Kirner et al. (2011) elsewhere.

\section{Conclusions}

With the submodel PSC it is possible to simulate the polar stratospheric clouds and their feedbacks to the chemistry including denitrification and dehydration. Due to two different NAT parameterisations and due to various parameters in the PSC namelists the submodel is highly flexible and can be setup according to different scientific theories of PSC formation and development.

Acknowledgements. The authors would like to thank Volker Grewe of DLR for his helpful comments on the manuscript.

Edited by: V. Grewe

\section{References}

Abbatt, J. P. D. and Molina, M. J.: The heterogeneous reaction of $\mathrm{HOCl}+\mathrm{HCl} \rightarrow \mathrm{Cl}_{2}+\mathrm{H}_{2} \mathrm{O}$ on ice and nitric-acid trihydrate reaction probabilities and stratospheric implications, Geophys. Res. Lett., 19, 461-464, 1992.

Bertram, A. K., Patterson, D. D., and Sloan, J. J.: Mechanisms and temperatures for the freezing of sulfuric acid aerosols measured by FTIR extinction spectroscopy, J. Phys. Chem., 100, 23762383, 1996.

Beyer, K. D., Seago, S. W., Chang, H. Y., and Molina, M. J.: Composition and freezing of aqueous $\mathrm{H}_{2} \mathrm{SO}_{4}-\mathrm{HNO}_{3}$ solutions under polar stratospheric conditions, Geophys. Res. Lett., 21, 871-874, 1994.

Biermann, U. M., Crowley, J. N., Huthwelker, T., Moortgat, G. K., Crutzen, P. J., and Peter, T.: FTIR studies on lifetime prolongation of stratospheric ice particles due to NAT coating, Geophys. Res. Lett., 25, 3939-3942, 1998.

Buchholz, J.: Simulations of physics and chemistry of polar stratospheric clouds with a general circulation model, $\mathrm{PhD}$ thesis, Johannes Gutenberg University Mainz, Germany, 2005.

Carslaw, K. S., Luo, B. P., Clegg, S. L., Peter, T., Brimblecombe, P., and Crutzen, P. J.: Stratospheric aerosol growth and $\mathrm{HNO}_{3}$ gas phase depletion from coupled $\mathrm{HNO}_{3}$ and water uptake by liquid particles, Geophys. Res. Lett., 21, 2479-2482, 1994.

Carslaw, K. S., Clegg, S. L., and Brimblecombe, P.: A thermodynamic model of the system $\mathrm{HCl}-\mathrm{HNO}_{3}-\mathrm{H}_{2} \mathrm{SO}_{4}-\mathrm{H}_{2} \mathrm{O}$ including solubilities of $\mathrm{HBr}$, from $<200 \mathrm{~K}$ to $328 \mathrm{~K}$, J. Phys. Chem., 99, 11557-11574, 1995a.

Carslaw, K. S., Luo, B., and Peter, T.: An analytic expression for the composition of aqueous $\mathrm{HNO}_{3}-\mathrm{H}_{2} \mathrm{SO}_{4}$ stratospheric aerosols including gas phase removal of $\mathrm{HNO}_{3}$, Geophys. Res. Lett., 22(14), 1877-1880, 1995 b.

Carslaw, K. S., Peter, T., and Clegg, S. L.: Modeling the composition of liquid stratospheric aerosols, Rev. Geophys., 35, 125-154, 1997.

Carslaw, K. S. Wirth, M., Tsias, A., Luo, B. P., Dörnbrack, A., Leutbecher, M., Volkert, H., Renger, W., Bacmeister, J. T., and Peter, T.: Particle microphysics and chemistry in remotely observed mountain polar stratospheric clouds, J. Geophys. Res., 103(D5), 5785-5796, doi:10.1029/97JD03626, 1998.

Carslaw, K. S., Kettleborough, J. A., Northway, M. J., Davies, S., Gao, R. S., Fahey, D. W., Baumgardner, D. G., Chipperfield, M. P., and Kleinböhl, A.: A vortex-scale simulation of the growth and sedimentation of large nitric acid hydrate particles, J. Geophys. Res., 107(D20), 8300, doi:10.1029/2001JD000467, 2002.

Crutzen, P. J., Müller, R., Brühl, C., and Peter, T.: On the potential importance of the gas-phase reaction $\mathrm{CH}_{3} \mathrm{O}_{2}+\mathrm{ClO} \longrightarrow \mathrm{ClOO}$ $+\mathrm{CH}_{3} \mathrm{O}$ and the heterogeneous reaction $\mathrm{HOCl}+\mathrm{HCl} \longrightarrow \mathrm{H}_{2} \mathrm{O}$ $+\mathrm{Cl}_{2}$ in ozone hole chemistry, Geophys. Res. Lett., 19, 11131116, 1992. 
Daerden, F., Larsen, N., Chabrillat, S., Errera, Q., Bonjean, S., Fonteyn, D., Hoppel, K., and Fromm, M.: A 3D-CTM with detailed online PSC-microphysics: analysis of the Antarctic winter 2003 by comparison with satellite observations, Atmos. Chem. Phys., 7, 1755-1772, doi:10.5194/acp-7-1755-2007, 2007.

DeMott, P., Rogers, D., and Kreidenweis, S.: The susceptibility of ice formation in upper tropospheric clouds to insoluble aerosol components, J. Geophys. Res., 102, 19575-19584, 1997.

Dye, J. E., Baumgardener, D., Gandrud, B. W., Kawa, S. A., Kelly, K. K., Lowenstein, M., Ferry, G. V., Chan, K. R., and Gary, B. L.: Particle size distributions in Arctic polar stratospheric clouds, growth and freezing of sulphuric acid droplets, and implications for cloud formation, J. Geophys. Res., 97, 8015-8034, 1992.

Fahey, D. W., Gao, R. S., Carslaw, K. S., Kettleborough, J., Popp, P. J., Northway, M. J., Holecek, J. C., Ciciora, S. C., McLaughlin, R. J., Thompson, T. L., Winkler, R. H., Baumgardner, D. G., Gandrud, B., Wennberg, P. O., Dhaniyala, S., McKinney, K., Peter, T., Salawitch, R. J., Bui, T. P., Elkins, J. W., Webster, C. R., Atlas, E. L., Jost, H., Wilson, J. C., Herman, R. L., Kleinböhl, A., and von König, M.: The Detection of Large $\mathrm{HNO}_{3}$-Containing Particles in the Winter Arctic Stratosphere, Science, 291, 10261031, 2001.

Fortin, T. J., Drdla, K., Iraci, L. T., and Tolbert, M. A.: Ice condensation on sulfuric acid tetrahydrate: Implications for polar stratospheric ice clouds, Atmos. Chem. Phys., 3, 987-997, doi:10.5194/acp-3-987-2003, 2003.

Graedel, T. E. and Crutzen, P. J.: Atmospheric Change: An Earth System Perspective, Freeman, New York, 1993.

Grainger R. G., Lambert, A., Rodgers, C. D., Taylor, F. W., and Desher, T.: Stratospheric aerosol effective radius, surface area and volume estimated from infrared measurements, J. Geophys. Res., 100, 16507-16518, 1995.

Grooß, J.-U.: Modelling of Stratospheric Chemistry based on HALOE/UARS Satellite Data, PhD thesis, Universität Mainz, Germany, 1996.

Hanson, D. R. and Mauersberger K.: Laboratory studies of the nitric acid trihydrate: implications for the south polar stratosphere, Geophys. Res. Lett., 15, 855-858, 1988.

Hanson, D. R. and Ravishankara, A. R.: The reaction probabilities of $\mathrm{ClONO}_{2}$ and $\mathrm{N}_{2} \mathrm{O}_{5}$ on polar stratospheric cloud materials, J. Geophys. Res., 96, 5081-5090, 1991.

Hanson, D. R. and Ravishankara, A. R.: The reaction of $\mathrm{ClONO}_{2}$ with $\mathrm{HCl}$ on NAT, NAD, and frozen sulfuric acid and hydrolysis of $\mathrm{N}_{2} \mathrm{O}_{5}$ and $\mathrm{ClONO}_{2}$ on frozen sulfuric acid, J. Geophys. Res., 96, 22931-22936, 1993.

Hanson, D. R. and Ravishankara, A. R.: Reactiv uptake of $\mathrm{ClONO}_{2}$ onto sulfuric acid due to reation with $\mathrm{HCl}$ and $\mathrm{H}_{2} \mathrm{O}$, J. Phys. Chem., 98, 5728-5735, 1994.

Hanson, D. R. and Ravishankara, A. R.: Heterogeneous chemistry of Bromine species in sulfuric acid under stratospheric conditions, Geophys. Res. Lett., 22, 385-388, 1995.

Hanson, D. R., Raishankara, A. R., and Lovejoy, E. R.: Reaction of $\mathrm{BrONO}_{2}$ with $\mathrm{H}_{2} \mathrm{O}$ on submicron sulfuric acid aerosol and the implications for the lower stratosphere, J. Geophys. Res., 101, 9063-9069, 1996.

Huthwelker T., Peter, T., Luo, B. P., Clegg, S. L., Carslaw, K. S., and Brimblecombe, P.: Solubility of $\mathrm{HOCl}$ in Water and aqueous $\mathrm{H}_{2} \mathrm{SO}_{4}$ to stratospheric temperatures, J. Atmos. Chem., 21, 8195, 1995.
Jensen, E. J. and Toon, O. B.: The potential impact of soot particles from aircraft exhaust on cirrus clouds, Geophys. Res. Lett., 24, 249-252, 1997.

Jöckel, P., Sander, R., Kerkweg, A., Tost, H., and Lelieveld, J.: Technical Note: The Modular Earth Submodel System (MESSy) - a new approach towards Earth System Modeling, Atmos. Chem. Phys., 5, 433-444, doi:10.5194/acp-5-433-2005, 2005.

Jöckel, P., Tost, H., Pozzer, A., Brühl, C., Buchholz, J., Ganzeveld, L., Hoor, P., Kerkweg, A., Lawrence, M. G., Sander, R., Steil, B., Stiller, G., Tanarhte, M., Taraborrelli, D., van Aardenne, J., and Lelieveld, J.: The atmospheric chemistry general circulation model ECHAM5/MESSy1: consistent simulation of ozone from the surface to the mesosphere, Atmos. Chem. Phys., 6, 50675104, doi:10.5194/acp-6-5067-2006, 2006.

Jöckel, P., Kerkweg, A., Buchholz-Dietsch, J., Tost, H., Sander, R., and Pozzer, A.: Technical Note: Coupling of chemical processes with the Modular Earth Submodel System (MESSy) submodel TRACER, Atmos. Chem. Phys., 8, 1677-1687, doi:10.5194/acp8-1677-2008, 2008.

Junge, C. E., Chagnon, C. W., and Manson, J. E.: Stratospheric aerosols, J. Meteorol., 18, 81-108, 1961.

Kerkweg, A., Buchholz, J., Ganzeveld, L., Pozzer, A., Tost, H., and Jöckel, P.: Technical Note: An implementation of the dry removal processes DRY DEPosition and SEDImentation in the Modular Earth Submodel System (MESSy), Atmos. Chem. Phys., 6, 4617-4632, doi:10.5194/acp-6-4617-2006, 2006a.

Kerkweg, A., Sander, R., Tost, H., and Jöckel, P.: Technical note: Implementation of prescribed (OFFLEM), calculated (ONLEM), and pseudo-emissions (TNUDGE) of chemical species in the Modular Earth Submodel System (MESSy), Atmos. Chem. Phys., 6, 3603-3609, doi:10.5194/acp-6-3603-2006, 2006b.

Kirner, O.: Prozessstudien der stratosphärischen Chemie und Dynamik mit Hilfe des Chemie-Klima-Modells ECHAM5/MESSy1, PhD thesis, Universität Karsruhe, Germany, 2008.

Kirner, O., Ruhnke, R., Höpfner, M., Jöckel, P., and Fischer, H.: A new parameterisation of polar stratospheric clouds (PSC) based on the efficient growth and sedimentation of NAT particles in the chemistry-climate-model EMAC, Atmos. Chem. Phys. Discuss., in preparation, 2011.

Koop, T., Luo, B., Tsias, A., and Peter, T.: Water activity as the determinant for homogeneous ice nucleation is aqueous solutions, Nature, 406, 611-614, 2000.

Landgraf, J. and Crutzen, P. J.: An efficient method for online calculations of photolysis and heating rates, J. Atmos. Sci., 55, 863878, 1998.

Lowe, D. and MacKenzie, A. R.: Polar stratospheric cloud microphysics and chemistry, J. Atmos. Sol.-Terr. Phy., 70, 13-40, 2008.

Luo, B. P., Carslaw, K. S., Peter, T., and Clegg, S. L.: Vapor pressures of $\mathrm{H}_{2} \mathrm{SO}_{4} / \mathrm{HNO}_{3} / \mathrm{HCl} / \mathrm{HBr} / \mathrm{H}_{2} \mathrm{O}$ solutions to low stratospheric temperatures, Geophys. Res. Lett., 22, 247-250, 1995.

Marti, J. and Mauersberger, K.: A survey and new measurements of ice vapor pressure at temperatures between 170 and $250 \mathrm{~K}$, Geophys. Res. Lett., 20, 363-366, 1993.

Meilinger, S. K.: Heterogeneous Chemistry in the Tropopause Region: Impact of Aircraft Emissions, PhD thesis, Swiss Federal Institute of Technology (ETH), Zürich, Switzerland, 2000.

Middlebrook, A. M., Tolbert, M. A., and Drdla, K.: Evaporation 
studies of model polar straospheric cloud films, Geophys. Res. Lett., 23, 2145-2148, 1996.

Molina, L. T. and Molina, M. J.: Production of $\mathrm{Cl}_{2} \mathrm{O}_{2}$ form the self-reaction of the ClO-Radical, J. Phys. Chem., 91, 433-436, 1987.

Müller, R.: Die Chemie des Ozons in der polaren Stratosphare, PhD thesis, Freie Universitat Berlin, Germany, 1994.

Roeckner, E., Brokopf, R., Esch, M., Giorgetta, M., Hagemann, S., Koernblueh, L., Manzini, E., Schlese, U., and Schulzweida, U.: Sensitivity of simulated climate to horizontal and vertical resolution in the ECHAM5 atmosphere model, J. Climate, 19, 3771-3791, 2006.

Sander, S. P., Friedl, R. R., Ravishankara, A. R., Golden, D. M., Kolb, C. E., Kurylo, M. J., Huie, R. E., Orkin, V. L., Molina, M. J., Moortgat, G. K., and Finlayson-Pitts, B. J.: Chemical Kinetics and Photochemical Data for Use in Atmospheric Studies - Evaluation Number 14, JPL Publication 02-25, Jet Propulsion Laboratory, Pasadena, USA, 2003.

Sander, R., Kerkweg, A., Jöckel, P., and Lelieveld, J.: Technical note: The new comprehensive atmospheric chemistry module MECCA, Atmos. Chem. Phys., 5, 445-450, doi:10.5194/acp-5445-2005, 2005.

Sander, S. P., Finlayson-Pitts, B. J., Friedl, R. R., Golden, D. M., Huie, R. E., Keller-Rudek, H., Kolb, C. E., Kurylo, M. J., Molina, M. J., Moortgat, G. K., Orkin, V. L., Ravishankara, A. R., and Wine, P. W.: Chemical Kinetics and Photochemical Data for Use in Atmospheric Studies - Evaluation Number 15, JPL Publication 06-2, Jet Propulsion Laboratory, Pasadena, 2006.

Schlager, H. and Arnold, F.: Measurement of stratospheric gaseous nitric acid in the Winter arctic vortex using a novel rocket-borne mass spectrometer method, Geophys. Res. Lett., 17, 433-436, 1990.

Solomon, S., Garcia, R. R., Rowland, F. S., and Wuebbles, D. J.: On the depletion of Antarctic ozone, Nature, 321, 755-758, 1986.

Tabazadeh, A., Turco, R. P. Drdla, K., and Jacobson, M. Z.: A model for studying the composition and chemical effects of stratospheric aerosols, J. Geophys. Res., 99, 12897-12914, 1994.

Tabazadeh, A., Toon, O. B., and Jensen, E. J.: Formation and implications of ice particle nucleation in the stratosphere, Geophys. Res. Lett., 24, 2007-2010, 1997.

Tabazadeh, A., Djikaev, Y. S., Hamill, P., and Reiss, H.: Laboratory evidence for surface nucleation of solid polar stratospheric cloud particles, J. Phys. Chem., 106, 10238-10246, 2002.

Tolbert, M. A., Rossi, M. J., Malhotra, R., and Golden, D. M.: Reaction of chlorine nitrate with hydrogen-chloride and water at Antarctic stratospheric temperatures, Science, 238, 1258-1260, 1987.
Tost, H., Jöckel, P., Kerkweg, A., Sander, R., and Lelieveld, J.: Technical note: A new comprehensive SCAVenging submodel for global atmospheric chemistry modelling, Atmos. Chem. Phys., 6, 565-574, doi:10.5194/acp-6-565-2006, 2006 a.

Tost, H., Jöckel, P., and Lelieveld, J.: Influence of different convection parameterisations in a GCM, Atmos. Chem. Phys., 6, 54755493, doi:10.5194/acp-6-5475-2006, 2006b.

Tost, H., Jöckel, P., Kerkweg, A., Pozzer, A., Sander, R., and Lelieveld, J.: Global cloud and precipitation chemistry and wet deposition: tropospheric model simulations with ECHAM5/MESSy1, Atmos. Chem. Phys., 7, 2733-2757, doi:10.5194/acp-7-2733-2007, 2007a.

Tost, H., Jöckel, P., and Lelieveld, J.: Lightning and convection parameterisations - uncertainties in global modelling, Atmos. Chem. Phys., 7, 4553-4568, doi:10.5194/acp-7-4553-2007, $2007 b$.

Tost, H., Lawrence, M. G., Brühl, C., Jöckel, P., The GABRIEL Team, and The SCOUT-O3-DARWIN/ACTIVE Team: Uncertainties in atmospheric chemistry modelling due to convection parameterisations and subsequent scavenging, Atmos. Chem. Phys., 10, 1931-1951, doi:10.5194/acp-10-1931-2010, 2010.

Turco, R. P., Toon, O. B., and Hamill, P.: Heteorogeneous physicochemistry of the polar ozone hole, J. Geophys. Res., 94, 1649316510, 1989

van den Broek, M. M. P., Williams, J. E., and Bregman, A.: Implementing growth and sedimentation of NAT particles in a global Eulerian model, Atmos. Chem. Phys., 4, 1869-1883, doi:10.5194/acp-4-1869-2004, 2004.

Waibel, A.: Anomalien ozonchemisch relevanter Spurengase, Dissertation an der Universität Heidelberg, Shaker, Aachen, Germany, 1997.

Waibel, A. E., Peter, T. H., Carslaw, K. S., Oelhaf, H., Wetzel, G., Crutzen, P. J., Poschl, U., Tsias, A., Reimer, V., and Fischer, H.: Arctic ozone loss due to denitrification, Science, 283, 2064 2069, 1999.

Walcek, C. J.: Minor flux adjustment near mixing ratio extremes for simplified yet highly accurate monotonic calculation of tracer advection, J. Geophys. Res., 105, 9335-9348, 2000.

Wirth, M., Tsias, A., Förnbrack, A., Weiß, V., Carslaw, K. S., Leutbecher, M., Renber, W., Volkert, H., and Peter, T.: Model-guided Lagrangian observation and simulation of mountain polar stratospheric clouds, J. Geophys. Res., 104, 23971-23981, 1999.

Wofsy, S., Salawitch, R., Yatteau, J., McElroy, M., Gandrud, B., Dye, J., and Baumgardner, D.: Condensation of $\mathrm{HNO}_{3}$ on falling ice particles: Mechanism for denitrification of the polar stratosphere, Geophys. Res. Lett., 17, 449-452, 1990. 